\title{
Full-Scale System for Quantifying Loads and Leak Rates of Seals for Space Applications
}

Patrick H. Dunlap, Jr. and Bruce M. Steinetz

Glenn Research Center, Cleveland, Ohio

Christopher C. Daniels and Janice L. Wasowski

The University of Akron, Akron, Ohio

Malcolm G. Robbie, Arthur H. Erker, Gary J. Drlik, and John J. Mayer

Analex Corporation, Cleveland, Ohio 


\section{NASA STI Program . . . in Profile}

Since its founding, NASA has been dedicated to the advancement of aeronautics and space science. The NASA Scientific and Technical Information (STI) program plays a key part in helping NASA maintain this important role.

The NASA STI Program operates under the auspices of the Agency Chief Information Officer. It collects, organizes, provides for archiving, and disseminates NASA's STI. The NASA STI program provides access to the NASA Aeronautics and Space Database and its public interface, the NASA Technical Reports Server, thus providing one of the largest collections of aeronautical and space science STI in the world. Results are published in both non-NASA channels and by NASA in the NASA STI Report Series, which includes the following report types:

- TECHNICAL PUBLICATION. Reports of completed research or a major significant phase of research that present the results of NASA programs and include extensive data or theoretical analysis. Includes compilations of significant scientific and technical data and information deemed to be of continuing reference value. NASA counterpart of peer-reviewed formal professional papers but has less stringent limitations on manuscript length and extent of graphic presentations.

- TECHNICAL MEMORANDUM. Scientific and technical findings that are preliminary or of specialized interest, e.g., quick release reports, working papers, and bibliographies that contain minimal annotation. Does not contain extensive analysis.

- CONTRACTOR REPORT. Scientific and technical findings by NASA-sponsored contractors and grantees.
- CONFERENCE PUBLICATION. Collected papers from scientific and technical conferences, symposia, seminars, or other meetings sponsored or cosponsored by NASA.

- SPECIAL PUBLICATION. Scientific, technical, or historical information from NASA programs, projects, and missions, often concerned with subjects having substantial public interest.

- TECHNICAL TRANSLATION. Englishlanguage translations of foreign scientific and technical material pertinent to NASA's mission.

Specialized services also include creating custom thesauri, building customized databases, organizing and publishing research results.

For more information about the NASA STI program, see the following:

- Access the NASA STI program home page at http://www.sti.nasa.gov

- E-mail your question via the Internet to help@ sti.nasa.gov

- Fax your question to the NASA STI Help Desk at $443-757-5803$

- Telephone the NASA STI Help Desk at 443-757-5802

- Write to: NASA Center for AeroSpace Information (CASI) 7115 Standard Drive Hanover, MD 21076-1320 


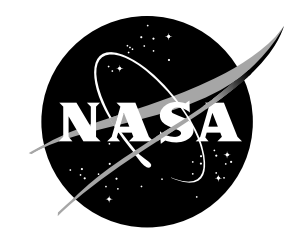

\section{Full-Scale System for Quantifying Loads and Leak Rates of Seals for Space Applications}

Patrick H. Dunlap, Jr. and Bruce M. Steinetz

Glenn Research Center, Cleveland, Ohio

Christopher C. Daniels and Janice L. Wasowski

The University of Akron, Akron, Ohio

Malcolm G. Robbie, Arthur H. Erker, Gary J. Drlik, and John J. Mayer

Analex Corporation, Cleveland, Ohio

Prepared for the

46th Joint Propulsion Conference and Exhibit

cosponsored by the AIAA, ASME, SAE, and ASEE

Nashville, Tennessee, July 25-28, 2010

National Aeronautics and

Space Administration

Glenn Research Center

Cleveland, Ohio 44135 


\section{Acknowledgments}

The authors would like to thank the Low Impact Docking System team from NASA Johnson Space Center for their support on this project. The authors would also like to acknowledge Instron Corporation (Norwood, MA) for fabricating the custom load frame, Standard Jig Boring Service (Akron, OH) for fabricating the main elements of the test fixture, and Erhard Hartman (Gilcrest Electrical \& Supply Company), Shawn Taylor (University of Toledo), and Nicholas Penney (Ohio Aerospace Institute) for their contributions in assembling and installing the test fixture hardware into the load frame and completing checkout tests.

Trade names and trademarks are used in this report for identification only. Their usage does not constitute an official endorsement, either expressed or implied, by the National Aeronautics and Space Administration.

Level of Review: This material has been technically reviewed by technical management.

Available from

NASA Center for Aerospace Information 7115 Standard Drive

Hanover, MD 21076-1320
National Technical Information Service 5301 Shawnee Road Alexandria, VA 22312

Available electronically at http://gltrs.grc.nasa.gov 


\title{
Full-Scale System for Quantifying Loads and Leak Rates of Seals for Space Applications
}

\author{
Patrick H. Dunlap, Jr. and Bruce M. Steinetz \\ National Aeronautics and Space Administration \\ Glenn Research Center \\ Cleveland, Ohio 44135 \\ Christopher C. Daniels and Janice L. Wasowski \\ The University of Akron \\ Akron, Ohio 44325-3901 \\ Malcolm G. Robbie, Arthur H. Erker, Gary J. Drlik, and John J. Mayer \\ Analex Corporation \\ Cleveland, Ohio 44135
}

\begin{abstract}
NASA is developing advanced space-rated vacuum seals in support of future space exploration missions to low-Earth orbit and other destinations. These seals may be 50 to 60 in. (127 to $152 \mathrm{~cm}$ ) in diameter and must exhibit extremely low leak rates to ensure that astronauts have sufficient breathable air for extended missions to the International Space Station or the Moon. Seal compression loads must be below prescribed limits so as not to overload the mechanisms that compress them during docking or mating, and seal adhesion forces must be low to allow two mated systems to separate when required. NASA Glenn Research Center has developed a new test apparatus to measure leak rates and compression and adhesion loads of candidate full-scale seals under simulated thermal, vacuum, and engagement conditions. Tests can be performed in seal-on-seal or seal-on-flange configurations at temperatures from -76 to $140{ }^{\circ} \mathrm{F}\left(-60\right.$ to $\left.60^{\circ} \mathrm{C}\right)$ under operational pressure gradients. Nominal and off-nominal mating conditions (e.g., incomplete seal compression) can also be simulated. This paper describes the main design features of the test apparatus as well as techniques used to overcome some of the design challenges.
\end{abstract}

\section{Nomenclature}

gpm gallons per minute

GRC NASA Glenn Research Center

ISS International Space Station

\subsection{Introduction}

NASA is developing advanced space-rated vacuum seals to seal the interfaces between docked or mated vehicles and structures for future space exploration missions. These seals can be relatively large with diameters on the order of 50 to $60 \mathrm{in}$. (127 to $152 \mathrm{~cm})$ and must exhibit extremely low leak rates to ensure that the astronauts have sufficient breathable air for extended missions to the International Space Station (ISS) or the Moon, for example. Mating can occur in an androgynous seal-on-seal configuration in which both sides of the interface have seals installed or in a seal-on-flange configuration with a seal on one side of the interface and a flat, smooth metal flange on the other. Figure 1 illustrates both of these configurations for a candidate Gask-O-Seal design (Parker Hannifin Corporation, San Diego, CA). 


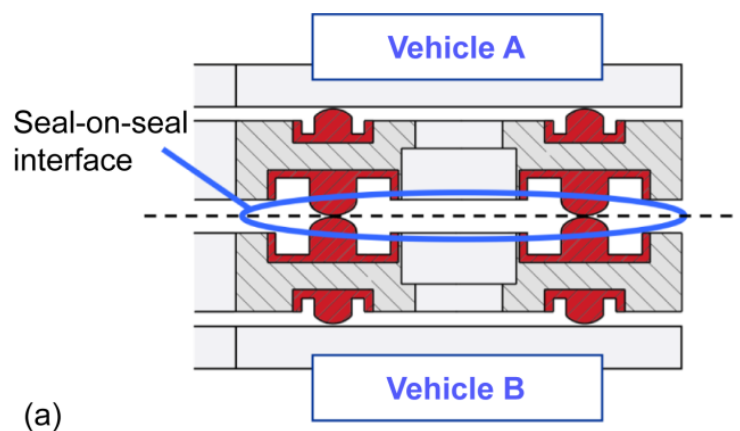

(a)

Figure 1.-Cross sections through the interface between two mated systems showing (a) seal-on-seal interface and (b) seal-on-flange interface.

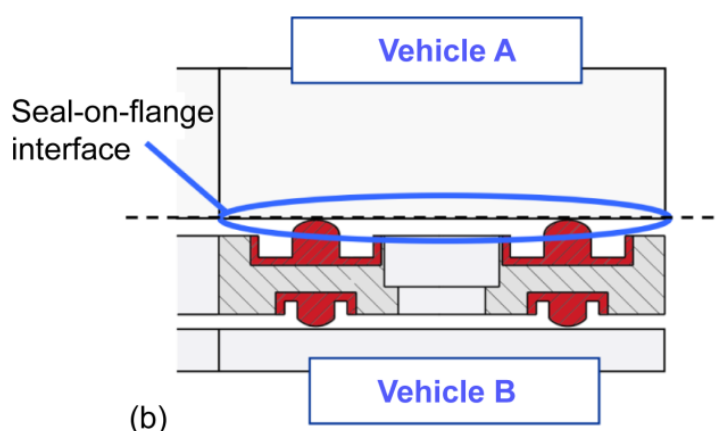

(b)

When two vehicles or structures mate during a mission, the seals at the interface between them will generate loads when they are compressed. To stay within the capabilities of the mechanisms that join the two vehicles together, the seal loads must stay below prescribed limits so that full closure can occur without overloading the mechanisms. When it comes time for the two mated systems to separate, the seals must exhibit very low adhesion forces to allow separation to occur. If the seal adhesion loads were too high, the ability of the systems to separate could be restricted.

\subsection{Test Apparatus Design Goals and Requirements}

To evaluate the performance of candidate seals under representative operating conditions, the NASA Glenn Research Center (GRC) has developed a new test apparatus that is capable of measuring leak rates, compression forces, and adhesion loads of candidate full-scale seal designs under simulated thermal, pressure, and engagement conditions. This paper describes the main design features of the test apparatus as well as techniques used to overcome some of the design challenges.

To guide the design of the test apparatus, a series of requirements was defined which are summarized in this section. Subsequent sections will address how these requirements were achieved.

\subsection{Mating Conditions and Interface Characteristics}

Because seal mating may occur in either a seal-on-seal or seal-on-flange configuration, the test apparatus had to be capable of performing tests in both mating arrangements. To achieve vacuum level sealing, a maximum surface roughness of $16 \mu \mathrm{in} .(0.41 \mu \mathrm{m})$ has been recommended (Ref. 1$)$. Therefore, sealing surfaces on the test apparatus had to have surface finishes of $16 \mu \mathrm{in}$. or better. The sealing surfaces on both sides of the interface also had to be precisely aligned so that the amount of compression on the seal test specimens could be carefully controlled.

\subsection{Different Seal Designs and Sizes}

Various seal designs are being developed for future applications, each with its own unique cross section. To accommodate these different designs, the test apparatus had to be capable of evaluating seals of different sizes including diameters as large as $60 \mathrm{in} .(152 \mathrm{~cm})$ and compressed seal heights up to 0.300 in. $(0.762 \mathrm{~cm})$. 


\subsection{Thermal Conditions}

The test apparatus had to be able to heat and cool the seal test specimens to simulate the thermal conditions that they would experience during a mission. This includes the following scenarios:

a. Both seals heated to at least $122^{\circ} \mathrm{F}\left(50^{\circ} \mathrm{C}\right)$,

b. Both seals cooled to at least $-58^{\circ} \mathrm{F}\left(-50^{\circ} \mathrm{C}\right)$,

c. One seal heated to $122^{\circ} \mathrm{F}$ and the other one cooled to $-58^{\circ} \mathrm{F}$,

d. Half of each seal heated and the other half cooled.

To achieve these conditions, the heating and cooling of each seal had to be done independently. Performing tests at cold temperatures required provisions to prevent condensation and ice from accumulating on the hardware during testing.

\subsection{Pressure Conditions}

The test apparatus had to be able to generate pressure differentials across the seals to simulate operating conditions in space. The nominal pressure differential across the seals was expected to be equivalent to atmospheric pressure with the inner diameter of the seals pressurized to approximately $14.7 \mathrm{psia}(101 \mathrm{kPa})$ and the outer diameter under vacuum pressure. To simulate these conditions, the test apparatus had to be able to generate a pressure on the order of 14.7 psia in the cavity inboard of the inner diameter of the seals while pulling a vacuum around the outer perimeter of the seals.

\subsection{Seal Leak Rates}

The test apparatus needed to be able to measure seal leak rates at the nominal pressure differential of 14.7 psid across the range of temperatures noted above. Under the pressure conditions described above, acceptable seal leak rates were expected to be on the order of $1 \times 10^{-4}$ to $1 \times 10^{-2} \mathrm{lbm}$ dry air/day thereby requiring accurate leak measurement systems.

\subsection{Seal Loads}

The test apparatus had to be able to compress the seal test specimens under the specified thermal conditions and measure the mechanical loads generated by the compressed seals. Forces on the order of $100 \mathrm{lbf}$ per in. (175 N per cm) of seal were anticipated resulting in total compression loads on the order of 35 to 40 kip for a pair of seals approximately 60 in. in diameter. In addition, the actuation system for the test apparatus needed to be capable of maintaining the seals in a compressed state with the cavity inboard of the seals pressurized during a leak test. Since seal adhesion forces were also of interest, the test apparatus had to be able to measure the amount of load required to unload and separate a seal test specimen from its mating surface at the end of a compression test or between compression cycles. Seal adhesion forces as low as several hundred pounds were anticipated.

\subsection{Engagement Conditions}

In some applications, seals may not be fully compressed when they are mated resulting in joint separation at the sealing interface. The test apparatus had to be capable of testing seals in either a fully compressed condition or in a partially compressed state with the distance between the sealing interfaces as large as 0.030 in. $(0.076 \mathrm{~cm})$. 


\subsection{Instrumentation}

The test apparatus required instrumentation to record seal leak rates and load data during testing. Pressure transducers were needed to measure pressure differentials across the seals at simulated operating conditions in space. Thermocouples were needed to measure the temperature distribution around each seal during testing. As noted above, load cells had to have the capacity to measure seal compression loads of 40 kip or more while also being sensitive enough to record seal adhesion loads in the hundreds of pounds in the tensile direction.

Health monitoring instrumentation was also required to ensure that pressures and temperatures in the test apparatus stay within predetermined safe ranges. Also, since the test apparatus was being designed to generate high compression loads, a safety system was needed to ensure that operators would not be injured during testing.

\subsection{Test Apparatus Design and Attributes}

The new test apparatus consists of a specially-designed test fixture integrated into a custom load frame (Figure 2). The design meets the aforementioned requirements and is capable of performing compression, adhesion, and leak tests on a variety of candidate seal designs and sizes in either a seal-onseal or seal-on-flange mating configuration. Tests can be performed under the desired thermal, pressure, and engagement conditions mentioned previously. Instrumentation is located throughout the test apparatus to quantify seal performance during testing and for health monitoring purposes. The following sections describe how the design goals were met for this test apparatus.

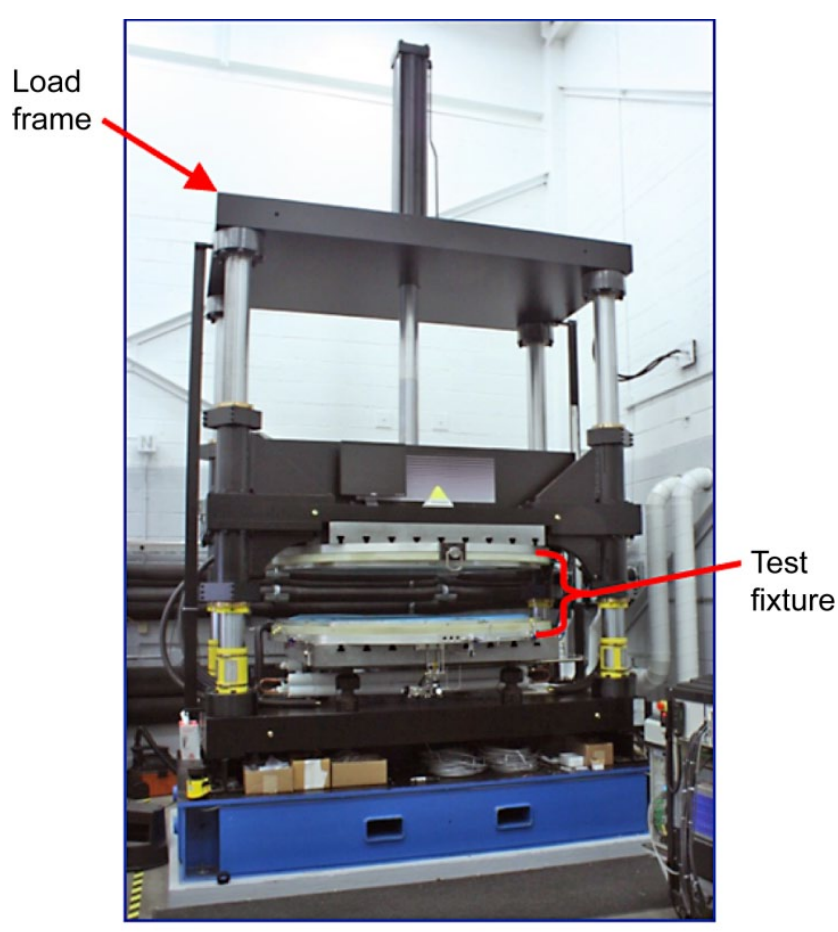

Figure 2.-Photograph of test apparatus. 


\subsection{Load Frame}

At almost $17 \mathrm{ft}$ tall, the main structural element of the new test apparatus is a custom $600 \mathrm{kN}$ load frame designed and built by Instron Corporation (Norwood, MA) (Figure 3). It includes an overhead mounted hydraulic actuator capable of generating up to $112.5 \mathrm{kip}(500 \mathrm{kN})$ in compression and 18 kip $(80 \mathrm{kN})$ in tension. The actuator was sized so that it could compress the seal test specimens and the large O-rings that seal the cavities inboard and outboard of the test seal during a leak test. It is also capable of maintaining all these seals in a compressed state while the cavity inboard of the seals is pressurized during a leak test. The actuator rod passes through the upper base plate and connects to the movable crosshead on which the upper half of the test fixture is installed. The actuator has a 54 in. $(137 \mathrm{~cm})$ stroke allowing it to raise the upper half of the test fixture between tests to permit access for seal test specimen installation and test fixture maintenance.

The upper and lower base plates are supported by four columns to form a stiff structure against which test forces can react. The load frame and actuator are both sized so that they can withstand a moment load of 6000 in.-lb (i.e., $100 \mathrm{kip}$ at 0.06 in. off center) to accommodate off axis loading conditions. The movable crosshead travels along the four columns on zero backlash bronze bushing assemblies that align the upper and lower halves of the test fixture to a parallelism of 0.001 in. per horizontal linear $\mathrm{ft}$.

Upper and lower T-slotted plates are mounted on both the movable crosshead and the fixed lower base plate, respectively (Figure 3 and Figure 4). The seal test fixture hardware is secured to these plates using bolts that are threaded into T-slot nuts that are inserted into the T-shaped grooves. The upper surface of the lower T-slotted plate and lower surface of the upper plate were both machined to a flatness of 0.002 in. Alignment holes in the center of each plate allow the upper and lower test fixture hardware to be aligned to the T-slotted plates to within 0.002 in. diametrically. The alignment holes and tight tolerances on flatness and parallelism allow the upper and lower halves of the test fixture to be aligned very precisely and provide a repeatable testing platform. Great care was taken in the design and fabrication of the load frame and test fixture to present a uniform engagement condition to the seal test specimen and to minimize bending moments on the test hardware and load frame.

An Instron 8800 Control Electronics Tower controls the load frame and provides signal conditioning and data acquisition during testing. The testing process is controlled by Partner Materials Testing Software provided by Instron. The controller is capable of controlling the speed of the actuator to within $0.001 \mathrm{in} . / \mathrm{s}$, and the software allows unique position versus time profiles to be input to simulate mating profiles during a mission.

\subsection{Base Support Structure}

Because the heavy load frame was originally only supported by I-beams below the lower base plate, there was a concern that locally high loads could be transferred to the floor of the laboratory thereby causing local settling and disturbing load frame stability. To overcome this potential issue, a support structure was designed and fabricated to serve as the base below the load frame to more evenly transfer loads to the laboratory floor (Figure 3). The analyses performed for the base support structure will be discussed in more detail in Section 4.0.

In addition to distributing the weight of the test apparatus on the floor, the base support structure includes features to aid in lifting and moving the test apparatus. A pair of slots is included in the front of the structure to allow the forks of a forklift to slide into the base (Figure 3). Also, pairs of holes are included on both sides of the structure so that lifting eyes can be installed. 


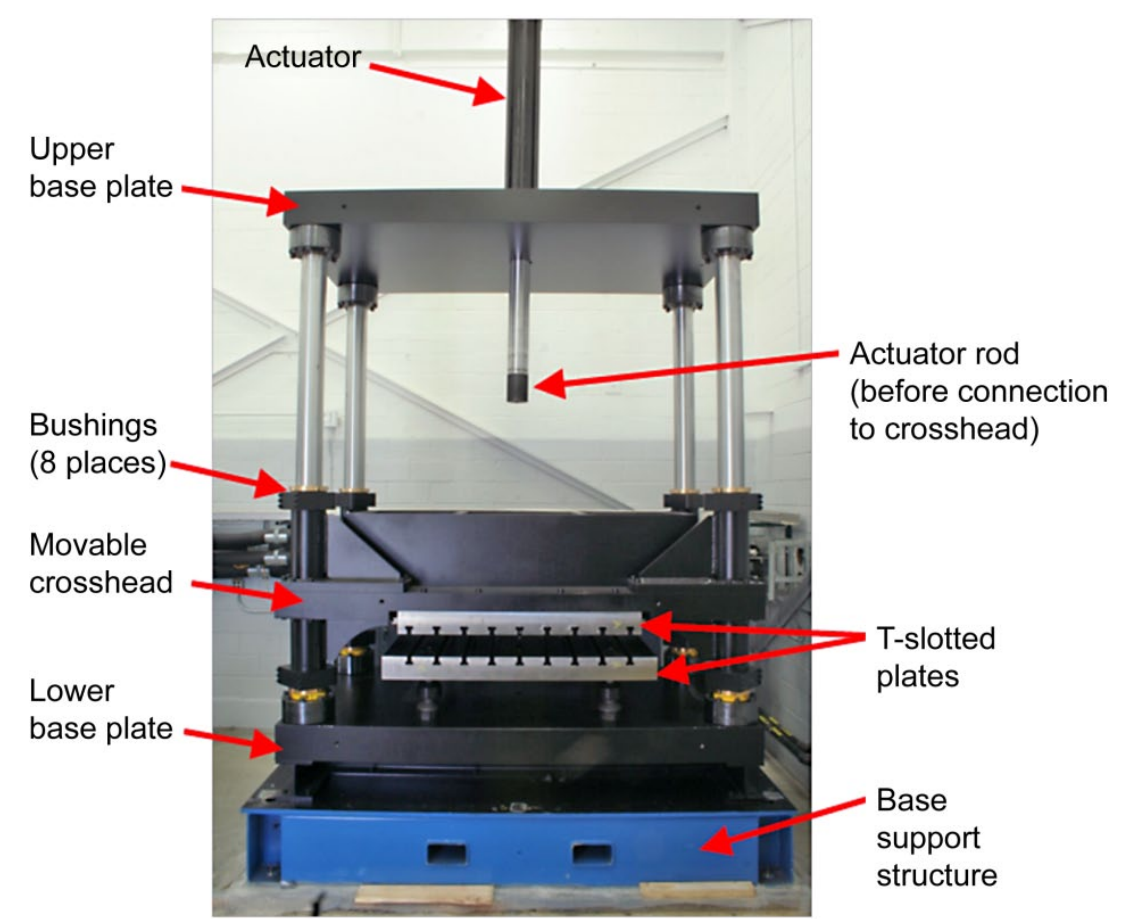

Figure 3.-Photograph of load frame before installation of test fixture.

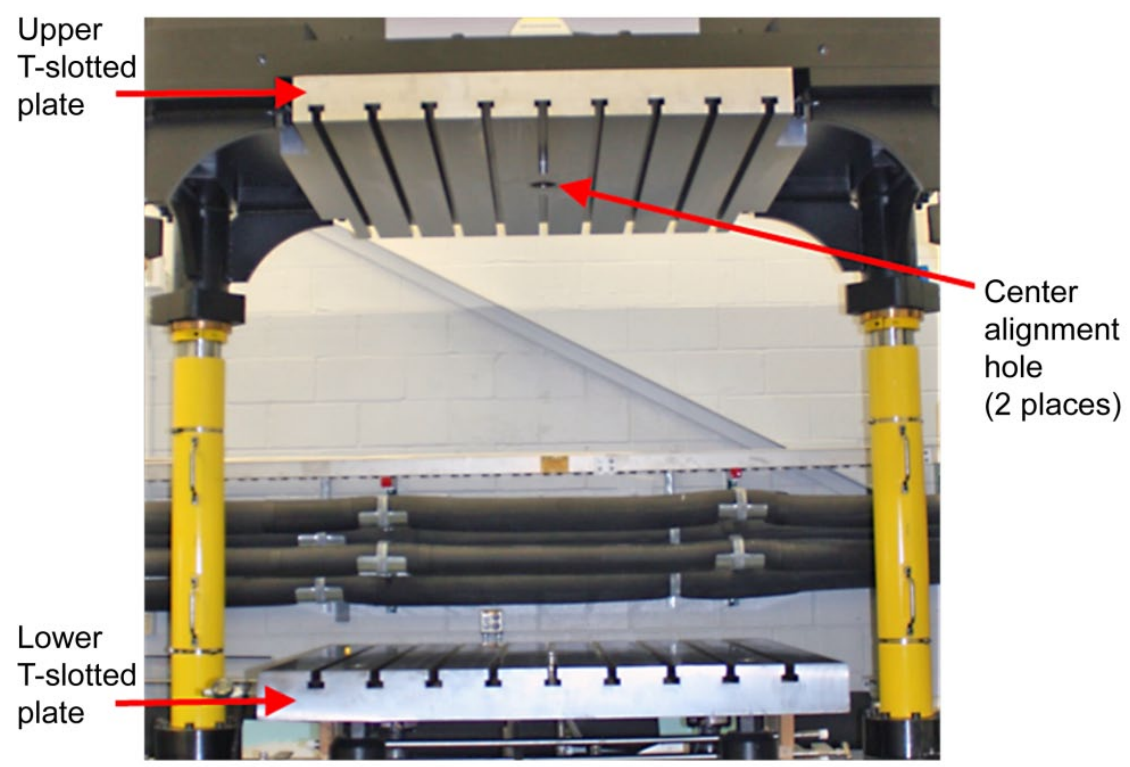

Figure 4.-Close up view of T-slotted plates before installation of test fixture.

\subsection{Test Fixture}

The basic design of the test fixture is very similar to that for a non-actuated (i.e., static) version of the test apparatus also developed by GRC (Ref. 2). However, the non-actuated version was developed for leak tests only, whereas the new actuated version is capable of performing seal compression and adhesion tests as well as leak tests. This updated version of the test fixture has been customized to allow for integration into the load frame (Figure 2), and it also includes several upgrades based on lessons learned while performing leak tests using the non-actuated version. The main elements of the test fixture are shown in Figure 5 and are described in detail in this section. 


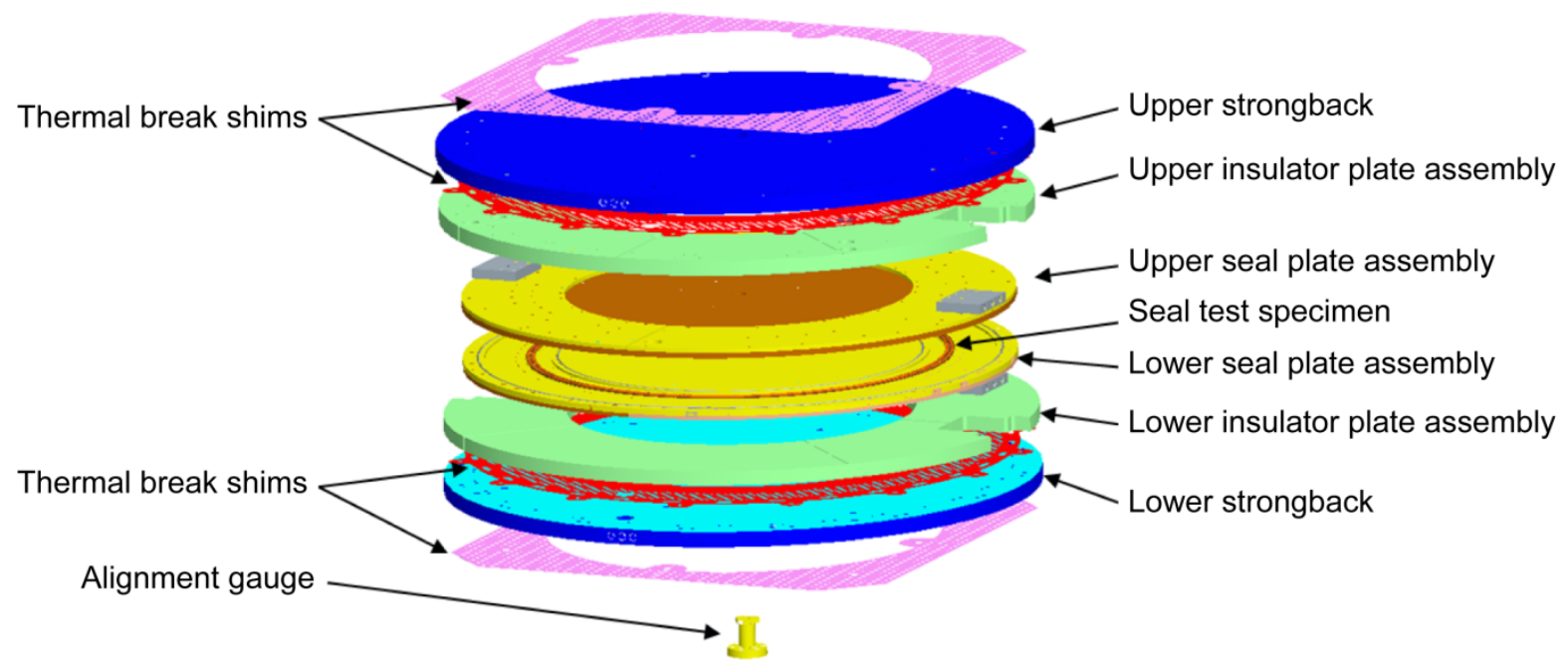

Figure 5.-Exploded view of main elements of test fixture.

\subsubsection{Seal Plate Assemblies}

At the mid-line of the test apparatus is a pair of seal plate assemblies (upper and lower) that hold the seal test specimens during testing (Figure 5). Each seal plate assembly is composed of a seal cartridge, a pair of heat exchanger plates, a pair of manifolds to distribute heat transfer fluid through the plates, and an assortment of O-rings that seal off various volumes in the test fixture (Figure 6).

To accommodate the variety of candidate seal sizes and designs that may be evaluated in the test apparatus, the seal cartridge contains a wide, annular pocket with an inner diameter of $47.6 \mathrm{in} .(121 \mathrm{~cm})$ and an outer diameter of 64.5 in. $(164 \mathrm{~cm})$ (Figure 6 and Figure 7). The oversized annular pocket allows a broad range of seal widths to be tested. The depth of the pocket for the initial build of seal cartridges is 0.30 in. $(0.76 \mathrm{~cm})$ across most of the pocket except for a raised land area with an inner diameter of 51.50 in. $(130.8 \mathrm{~cm})$ and an outer diameter of 54.25 in. $(137.8 \mathrm{~cm})$ where the depth is $0.20 \mathrm{in} .(0.51 \mathrm{~cm})$ (Figure 7). This unique depth profile was included so that a particular Gask-O-Seal design with a 54 in. outer diameter could be evaluated in the test apparatus. Different bolt patterns can be machined into this region so that seals of different sizes can be tested. Although the initial build was designed to test specific seals, the modular design of the test fixture allows different seal cartridges to be fabricated with other annular pocket designs to evaluate different seal designs.

The modular nature of the seal cartridge allows both seal-on-seal and seal-on-flange tests to be performed (Figure 1). For seal-on-seal testing, seal specimens are installed in both the upper and lower seal cartridges, and the seals are compressed against each other during a test (Figure 8(a)). These seals can be of the same or different designs as long as they are of comparable size and able to compress against each other. Figure 8(a) illustrates this configuration for two Gask-O-Seals of the same design compressed against each other.

Seal-on-flange tests can be performed two ways. In one configuration, the test seal is installed in the lower seal plate assembly, and an aluminum ring with a smooth, flat surface is installed in the upper assembly (Figure 8(b)). This ring is made of anodized 7075-T6 aluminum, and its sealing surface has a roughness of approximately $16 \mu \mathrm{in}$. with a circular lay. The back side of the ring is sealed by a pair of silicone O-rings to minimize leakage through the interface between the ring and the seal cartridge. The benefit of using a removable ring is that the effects of different surface finishes, coatings, or intentional defects can be evaluated by installing different rings without having to fabricate entirely new seal cartridges. However, the downside of this configuration is that it introduces an additional leak path behind the ring that may not be present in the actual application.

An alternate configuration for seal-on-flange tests utilizes a different upper seal cartridge design, one without the annular pocket and separate aluminum ring (Figure $8(\mathrm{c})$ ). The flat surface presented to the 
seal test specimen has a roughness of approximately $16 \mu \mathrm{in}$. with a circular lay and a flatness of $0.004 \mathrm{in}$. or better. This arrangement eliminates the leak path on the back side of the removable ring but does not provide the same level of testing flexibility that the removable ring does.

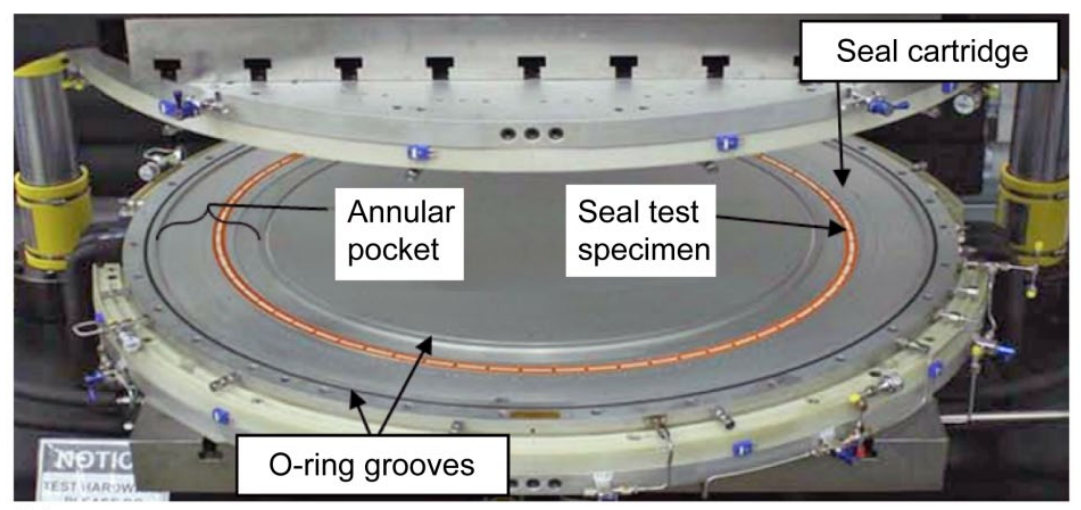

(a)

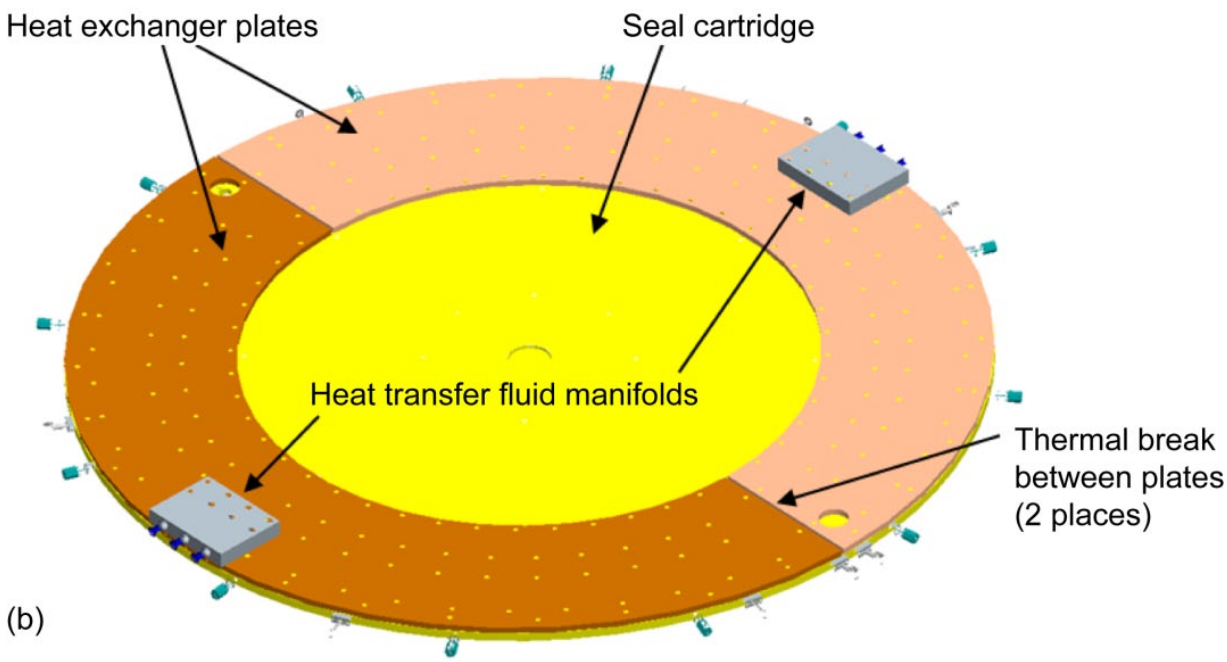

Figure 6.-Lower seal plate assembly: (a) Photograph of hardware installed in test apparatus, and (b) schematic of bottom side of assembly showing main components.

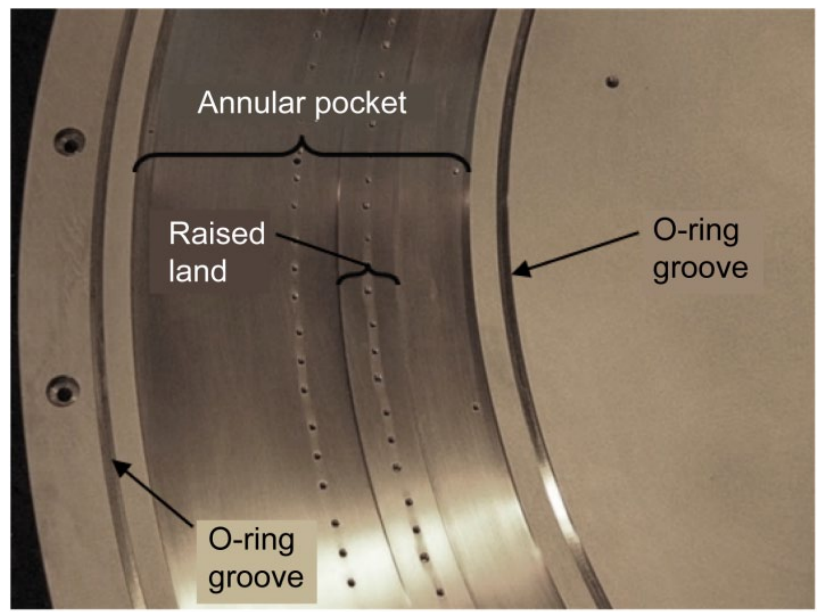

Figure 7.-Close up view of seal cartridge showing raised land in annular pocket. 

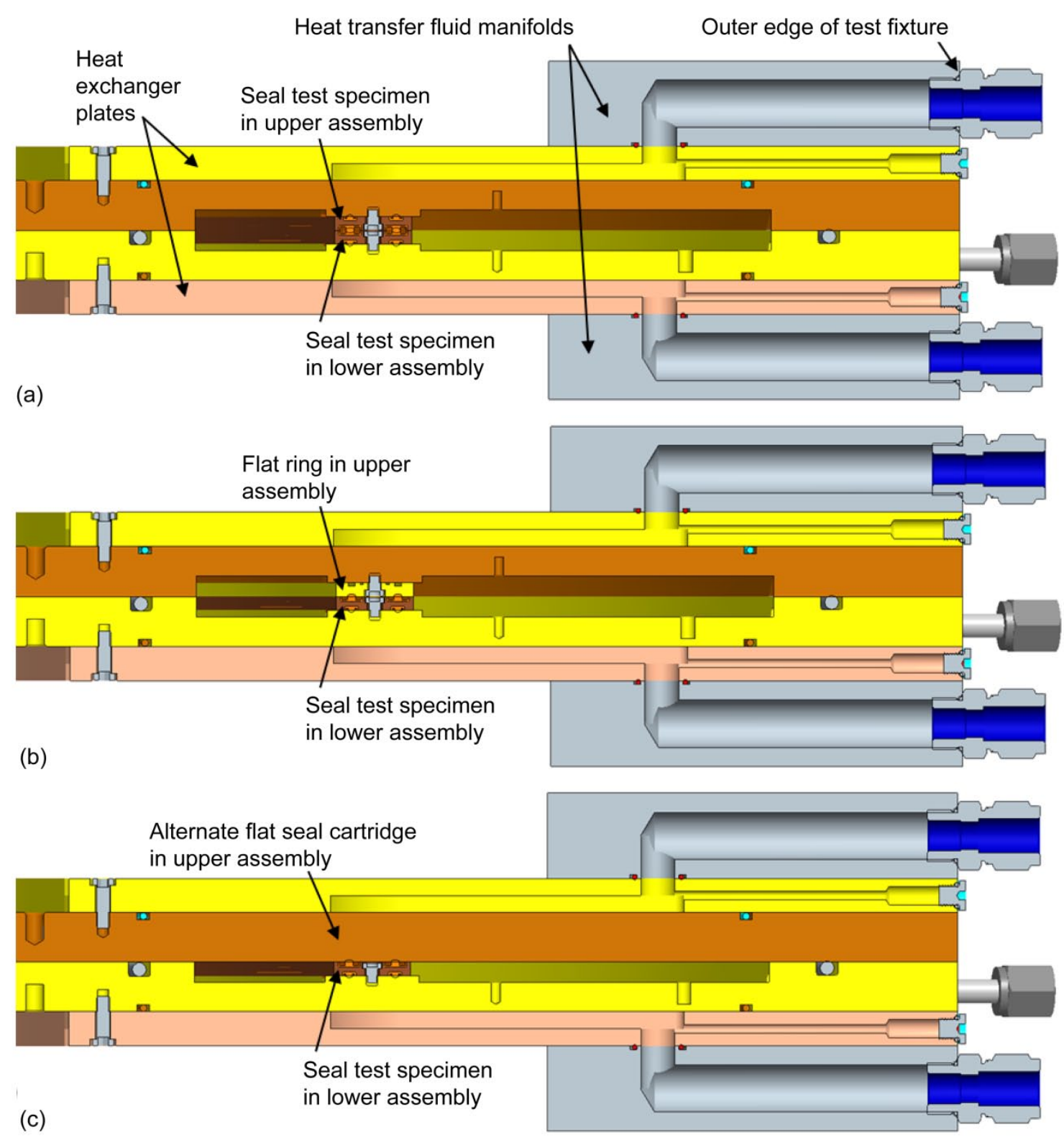

Figure 8.-Cross sections through test fixture illustrating: (a) seal-on-seal mating configuration, (b) sealon-flange mating configuration with removable flat ring installed in upper seal plate assembly, and (c) seal-on-flange mating configuration utilizing alternate upper seal cartridge design without removable flat ring. (Note: Test fixture centerline is to left and outer edge is to right in all views.)

The test apparatus is capable of testing seals in either a fully or partially compressed condition. This is accomplished by controlling the movement of the actuator to either fully compress the test seals or to stop short of full compression such that a gap exists between the upper and lower seal plate assemblies. This gap size can be set using precision pin gages and measured to within \pm 0.0002 in. by a pair of Heidenhain linear encoders mounted on the sides of the load frame. Since the size of this gap is driven by movement of the actuator and the actuator has a stroke of 54 in., the gap can be of any range of sizes from full compression to any other level of partial seal compression.

The lower seal plate assembly was designed to simulate the required pressure differentials across the seals during testing. Figure 9 shows how on-orbit pressure conditions are generated for seal leak tests. Note that the views shown in Figure 9 are taken from different cross sections through the test fixture 
because the ports are not all located in the same plane. A cross-drilled port in the cavity inboard of the test seal provides air at approximately atmospheric pressure to this region (Figure 9(a)). To prevent the entire cavity inboard of the test seal from being pressurized to atmospheric pressure, an O-ring is positioned just inboard of the port to create an annular region of higher pressure. On the outboard side of the seal, a large, 0.83 -in. diameter port located near the outer edge of the annular pocket is connected to a vacuum pump to draw the pressure in this region down to a gross vacuum pressure of 100 millitorr or less (Figure 9(b)). To facilitate this, the cavity outboard of the test specimen is sealed near the perimeter of the seal cartridge by an O-ring. Based on lessons learned during leak tests performed using the non-actuated version of the test apparatus (Refs. 3 and 4), this larger port was included in the new test fixture. During helium leak testing, the port is connected to a helium leak detector. The large port size provides a means for helium gas to more efficiently reach the detector allowing leak tests to be performed more quickly. The region between the elastomer bulbs of the test seal is also connected to a port to allow that area to be evacuated or pressurized during testing (Figure 9(c)). This arrangement allows a pressure differential of one atmosphere to be generated across either the inner or outer seal for a pair of seals or seal bulbs.

The test apparatus is capable of operating over a range of temperatures from -76 to $140{ }^{\circ} \mathrm{F}$ ( -60 to $60{ }^{\circ} \mathrm{C}$ ) thus permitting testing over a wider range than what was originally required (see Section 2.3). The desired thermal conditions for a given test are produced by a pair of heat exchanger plates installed on the back side of each seal plate assembly (Figure 6(b) and Figure 8). A Two-Loop Chiller/Heater, Model 2VLH30W (hereafter referred to as the "temperature control system") produced by Mydax, Incorporated (Auburn, CA) circulates Syltherm HF heat transfer fluid through the plates during testing to heat or cool

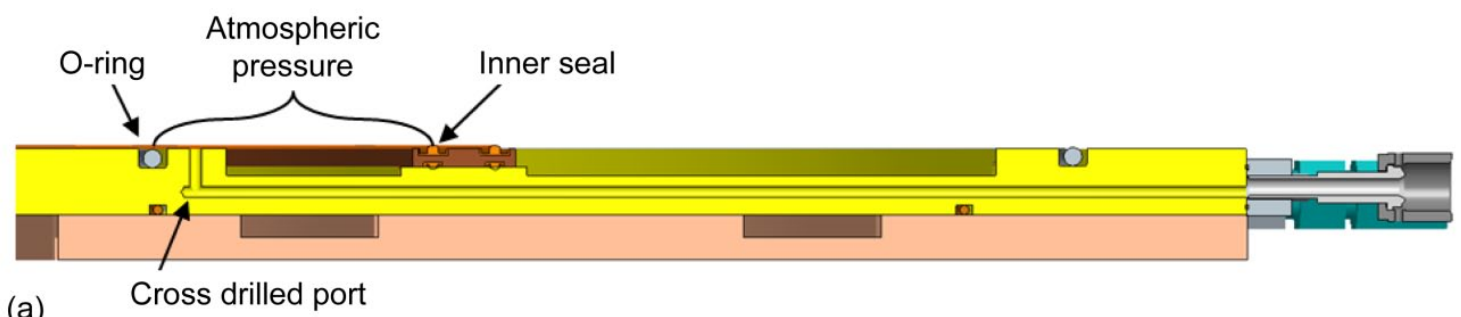

(a)
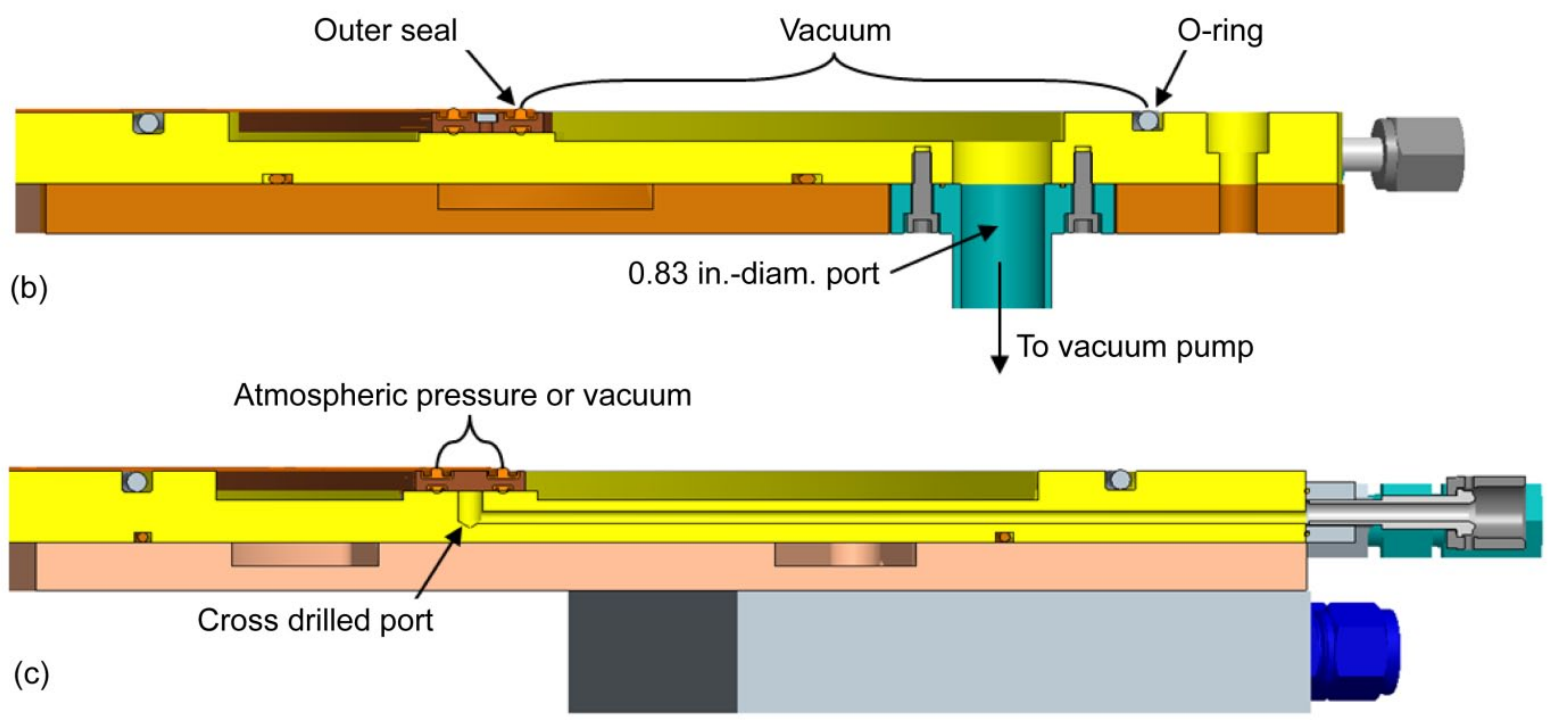

Figure 9.-Cross sections through lower seal plate assembly showing ports (a) inboard, (b) outboard, and (c) between seal bulbs and regions of atmospheric pressure and vacuum during leak testing. (Note: Test fixture centerline is to left and outer edge is to right in all views.) 
the test apparatus to the appropriate temperature and maintain that temperature for the duration of the test. The two separate heating/cooling loops of the temperature control system enable it to heat and cool each seal plate assembly independently to achieve test conditions in which the upper and lower seal plate assemblies are heated to either the same or different temperatures. The heat exchanger plates were also designed to heat or cool each half of a seal plate assembly independently by utilizing a configuration composed of two half rings with a thermal break between them (Figure 6(b)).

The heat transfer fluid is supplied to each heat exchanger plate through a manifold connected to the backside of each plate (Figure 6(b) and Figure 8). Once the fluid enters a plate, it flows radially inward toward the inner edge, splits into two symmetric paths that loop out to the ends of the plate, and then flows back along the outer edge to a pair of exhaust ports that return the fluid to the temperature control system (Figure 10). A fluorosilicone O-ring installed around the perimeter of the fluid passages contains the heat transfer fluid inside this sealed cavity. This same basic design for the heat exchanger plates was utilized for the non-actuated version of the test apparatus (Ref. 2). However, it did not include the manifolds attached to the backside of the plates. Instead, the heat transfer fluid was delivered through ports drilled directly into the outer edges of the heat exchanger plates (Figure 11). As shown in Figure 11, the fluid lines in the manifolds are larger than those for the original design. This new design allows the fluid to flow more freely into the heat exchanger plates without restriction. During checkout tests of the system with the manifolds installed, the fluid pressure in the system was on the order of 40 psig compared to about $90 \mathrm{psig}$ for the pressure in the non-actuated test apparatus using the original port design. Also, the fluid flow rate increased to 10 gallons per minute (gpm) compared to about 3 to $4 \mathrm{gpm}$ for the original design. The decreased fluid pressure and increased flow rate decreased the amount of time required to reach the desired test temperature. Using the new manifold design, the test apparatus was able to reach $-58^{\circ} \mathrm{F}\left(-50^{\circ} \mathrm{C}\right)$ in about 3 to $5 \mathrm{hr}$ whereas the non-actuated test apparatus could take as long as $28 \mathrm{hr}$ to reach $-22^{\circ} \mathrm{F}\left(-30^{\circ} \mathrm{C}\right)$ using the original design. Additional details on the capabilities of the temperature control system and the selection of the fluid passage layout can be found in the paper by Dunlap et al. (Ref. 2).

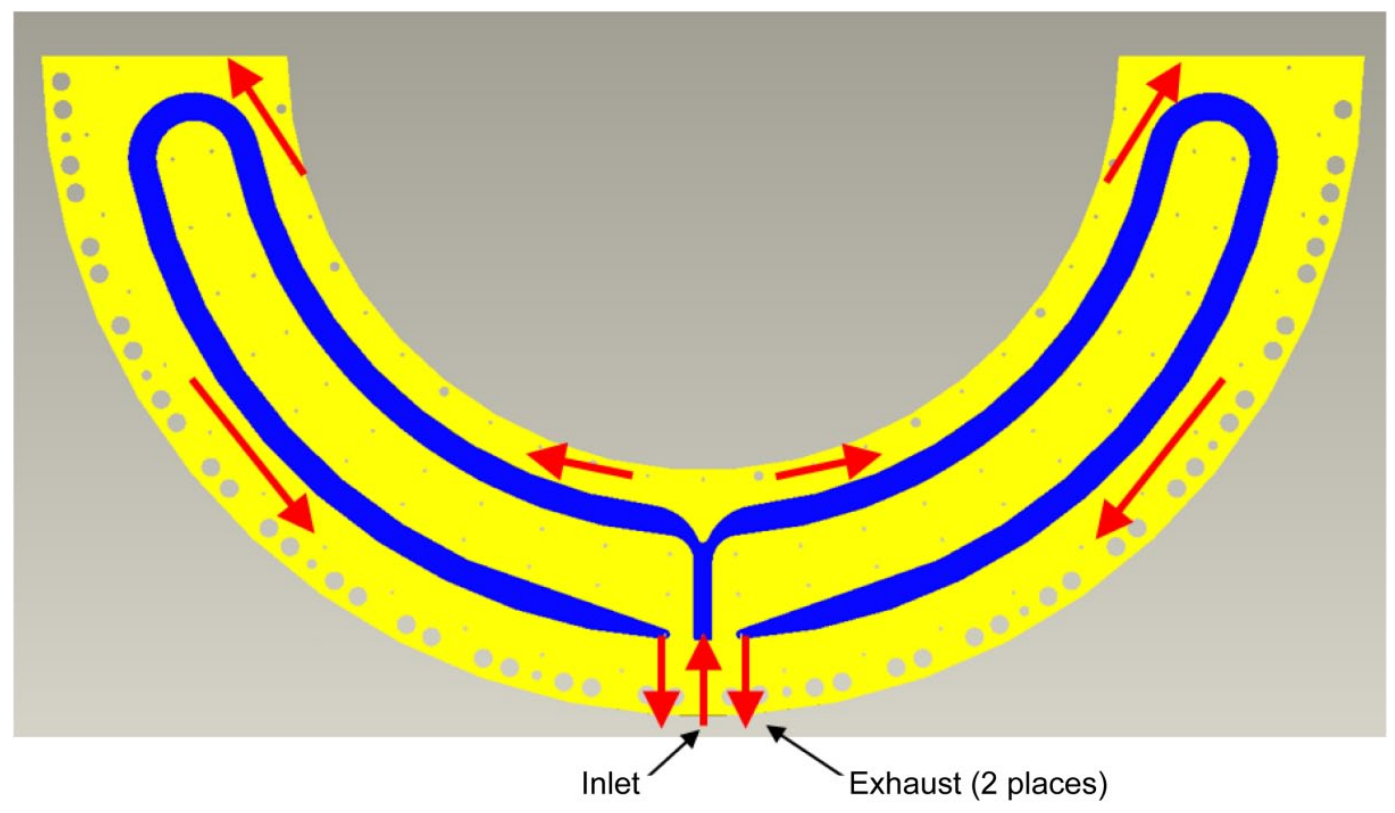

Figure 10.-Top view of heat exchanger plate showing layout of fluid passages. Note: Red arrows indicate direction of heat transfer fluid flow. 


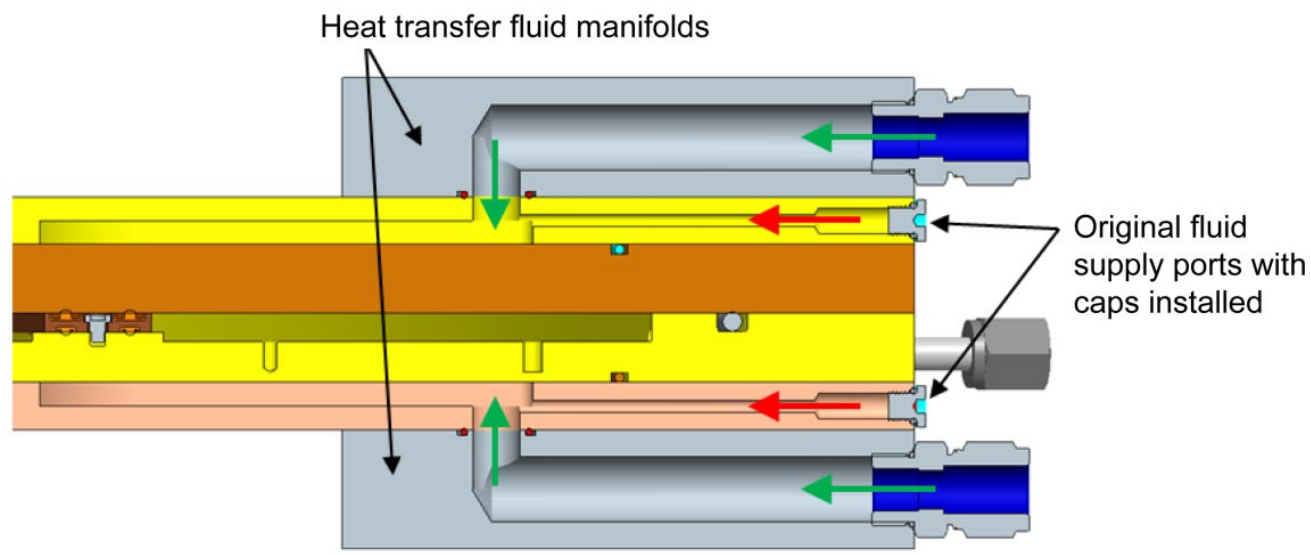

Figure 11.-Comparison of heat transfer fluid delivery methods: new manifold design versus original design. Green arrows indicate flow path through new manifolds. Red arrows indicate path through original ports.

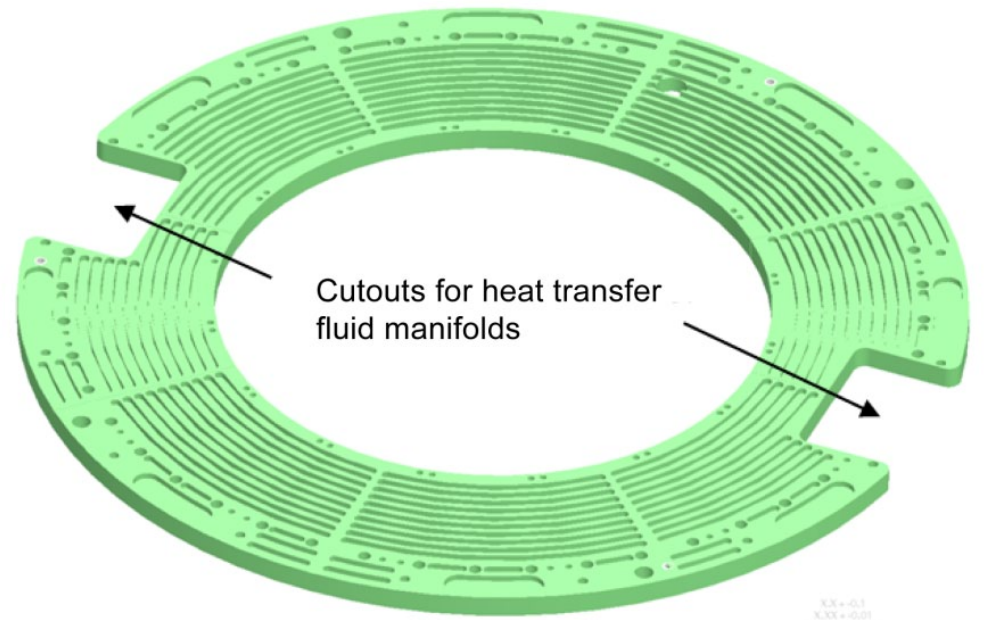

Figure 12.-Schematic of insulator plate showing machined pockets to reduce thermal conduction and cutouts for heat transfer fluid manifolds.

\subsubsection{Insulator Plate Assemblies}

Insulator plate assemblies are installed behind both the upper and lower seal plate assemblies to help maintain them at the desired temperature during testing (Figure 5). The material selected for the insulation is an epoxy-impregnated fiberglass laminate phenolic material (G10 FR4) that was also used as the insulating material for the non-actuated test apparatus (Ref. 2). This material has a relatively low thermal conductivity of 2 Btu-in. $/ \mathrm{hr}^{-} \mathrm{ft}^{2}{ }^{\circ} \mathrm{F}(0.288 \mathrm{~W} / \mathrm{m}-\mathrm{K})$, reducing heat transfer to a minimum (Ref. 5). For comparison purposes, the thermal conductivity of the 6061-T651 aluminum seal cartridges is almost 600

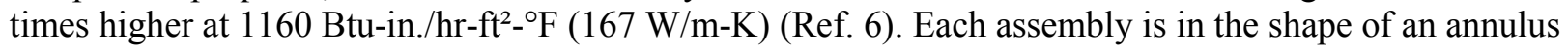
that is $1.88 \mathrm{in} .(4.76 \mathrm{~cm})$ thick with an inner diameter of $44.00 \mathrm{in} .(111.76 \mathrm{~cm})$ and an outer diameter of 75.13 in. (190.83 cm). (Figure 12) The assembly is composed of eight segments that are bonded together using epoxy.

Although a similar design was used for the non-actuated test apparatus, several modifications were made for the new test fixture to further minimize heat transfer through the insulator plate assemblies. The 
new design includes pockets machined into the insulator plates to minimize the amount of surface area in contact with the heat exchanger plates. In addition, thin stainless steel shims with a pattern of cutouts are installed between each insulator plate assembly and its adjacent strongback and between each strongback and T-slotted plate to reduce the contact areas between these surfaces (Figure 5). It is believed that these upgrades worked in conjunction with the new manifolds to decrease the amount of time required to reach the desired test temperature.

\subsubsection{Strongbacks}

The upper and lower strongbacks are the main structures of the test fixture to which the other assemblies attach (Figure 5). Each strongback is made of 6061-T651 aluminum and is $75.50 \mathrm{in}$. $(191.8 \mathrm{~cm})$ in diameter and $2.00 \mathrm{in} .(5.08 \mathrm{~cm})$ thick. After the insulator plate assemblies are attached to each strongback, the seal plate assemblies are attached using 32 fasteners per assembly. With the insulator plates installed between the seal plate assemblies and the strongbacks, these elements may reach different temperatures during testing. To accommodate this, Belleville springs are installed beneath the heads of the 32 fasteners to maintain a near-uniform preload on them and to prevent them from being overloaded and breaking as the seal plates and strongbacks move with respect to each other during thermal excursions (Figure 13).

As noted earlier, the lower T-slotted plate has an alignment hole in its center (Figure 4). A lobed alignment gage (Figure 5) is inserted into this hole and then mated with a similar hole in the bottom of the lower strongback to align the lower half of the test fixture to the lower T-slotted plate to within 0.002 in. radially. Once the lower half of the test fixture is aligned to the T-slotted plate, the upper half is aligned to the lower half using precision gauging. Great care is taken in aligning the test hardware so that seal-onseal tests can be performed with confidence knowing that the seals are aligned accurately.

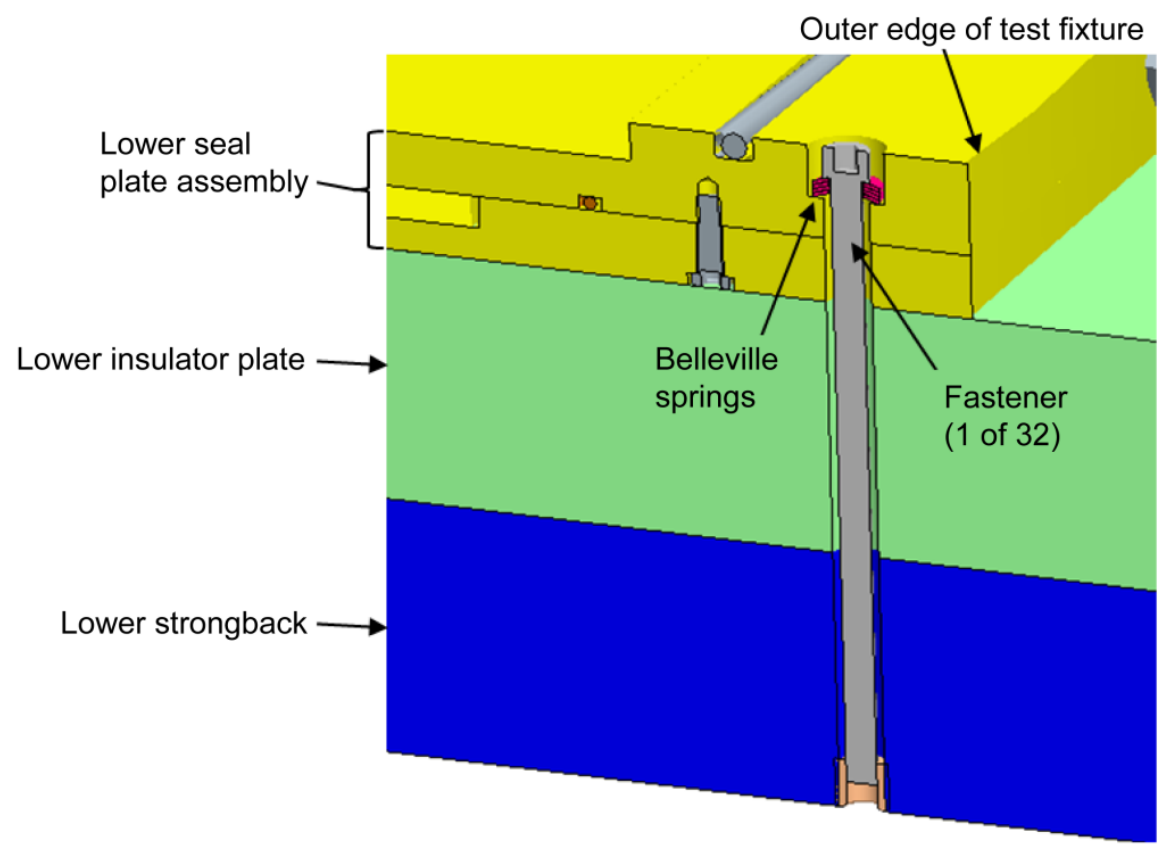

Figure 13.-Cross section showing Belleville springs beneath head of one of 32 fasteners used to attach lower seal plate assembly to lower strongback. 


\subsection{Safety System}

As noted earlier, the hydraulic actuator on the test apparatus is capable of generating up to $112.5 \mathrm{kip}$ of compressive load. Loads of this magnitude could seriously injure a person should they get caught between the upper and lower halves of the test fixture during testing. To ensure operator safety, designers of the test apparatus implemented a system of S300 safety laser scanners (Sick AG, Waldkirch, Germany) to shut it down if someone were to get too close to it during operation. The safety system consists of three scanners, two mounted on the front corners of the base support structure (Figure 14) and one on the backside of the structure in the center. Each scanner emits a horizontal light screen that scans the region around it, and the three units work together to provide coverage around the accessible perimeter of the test apparatus. The scanners are mounted at different heights at least 2 in. apart to ensure that the beams of adjacent scanners do not interfere with each other. During operation, the scanners have two adjustable ranges that they operate within: a larger region called the warning field and a smaller protective field. If a person or object enters the warning field when the scanners are on, an audible alarm sounds and a warning light flashes to alert the person to move away from the test apparatus. This range is set at $32 \mathrm{in}$. but can be adjusted if necessary. However, if someone or something enters the much smaller protective field range, the scanners send a signal to the load frame controller to stop the test and shut down. Use of the safety system is intended to keep both personnel and the test hardware safe during testing.

\subsection{Humidity Enclosure}

Because the test apparatus must be capable of performing tests at temperatures as low as $-58^{\circ} \mathrm{F}$ $\left(-50^{\circ} \mathrm{C}\right)$, condensation and ice could build up on the test hardware when testing at temperatures below the dew point if left unchecked. Excessive ice could prevent the upper and lower halves of the test fixture from closing completely thereby affecting measurements during testing. To minimize ice formation, an enclosure was designed to fit around the test apparatus (Figure 14). This enclosure has loosely sealed walls and a port into which dry air is supplied from compressed air " $\mathrm{K}$ "-bottles. Before a test begins, dry air at a very slight positive pressure is allowed to flow into the enclosure. The dry air displaces the humid air from the enclosure by forcing it out through narrow passages where the walls of the enclosure meet. Once the humidity has been displaced from around the test hardware, a test can begin with minimal condensation or ice forming.

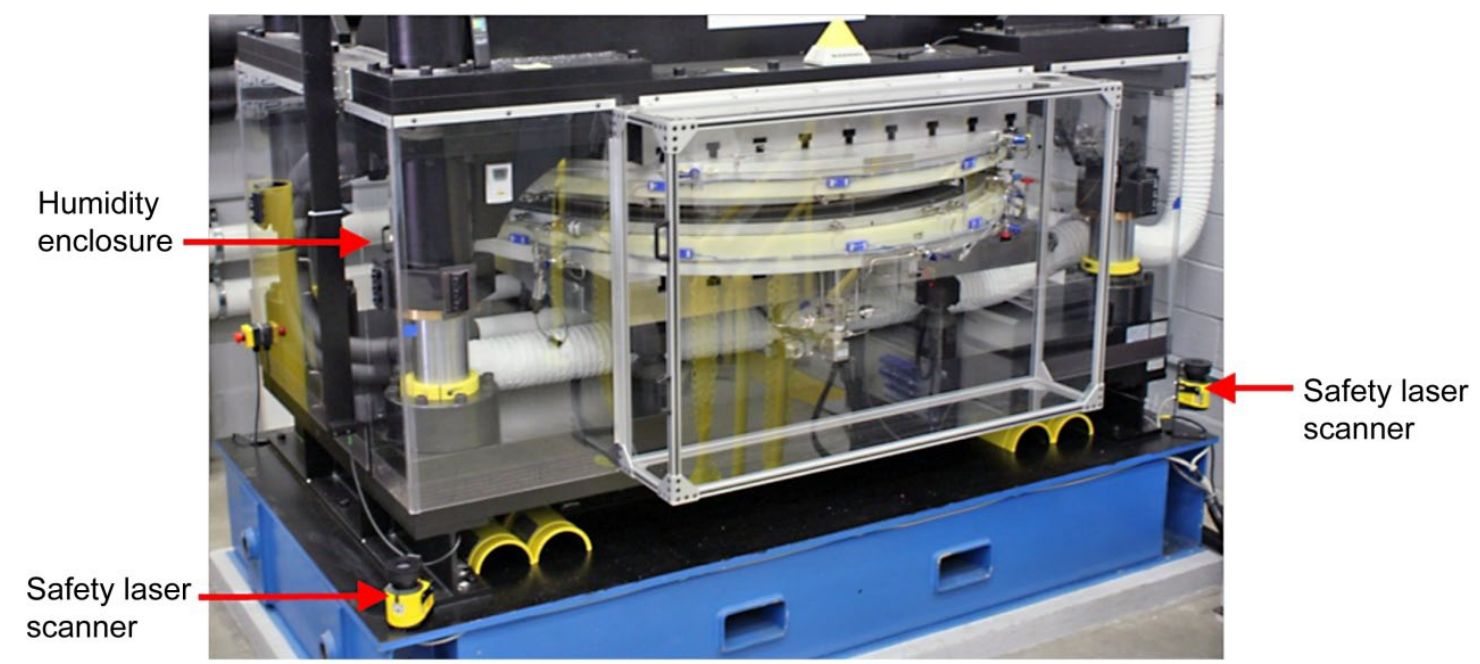

Figure 14.-Photograph of test apparatus showing two of the three safety laser scanners and humidity enclosure installed. Note that the safety scanner on the backside of the test apparatus is not shown. 


\subsection{Instrumentation}

Instrumentation is located throughout the test apparatus to quantify seal performance during load and leak testing. Seal compression and adhesion loads are measured by four load cells mounted on the lower base plate below the lower T-slotted plate (Figure 15). The load cells are spaced such that each supports one quadrant of the lower half of the test fixture. Each load cell has a capacity of 50 kip. During load testing, the position of the upper half of the test fixture and the amount of compression applied to the test seals are measured very accurately by a pair of Heidenhain linear encoders mounted on the sides of the load frame (Figure 15). Each device has a stroke of $56.7 \mathrm{in}$. and an accuracy of $\pm 0.0002 \mathrm{in}$.

Seal temperatures are measured by 24 equally-spaced type $\mathrm{T}$ thermocouples $\left( \pm 0.036^{\circ} \mathrm{C}\right.$ accuracy) divided equally between the two seal cartridges. Those in the lower seal cartridge are installed around the base of the test seal, while those in the upper cartridge are at the base of the opposing test seal or flat ring depending on the test configuration (i.e., seal-on-seal versus seal-on-flange). Additional type T thermocouples measure the air temperature inside the test apparatus enclosure, in the vacuum line, and in the laboratory.

The differential pressure across the test seal is measured during testing by a series of pressure transducers located inboard and outboard of the seal. The pressure on the high pressure side of the test section is monitored by two pressure transducers rated for pressures of 0 to $35 \mathrm{psia}$ ( 0 to $241 \mathrm{kPa}$ ) with a specified accuracy of \pm 0.75 percent of full scale. The pressure on the low pressure side of the test section is monitored by two vacuum transducers. The vacuum transducers have a range of 0.0001 to 100 torr $\left(1.33 \times 10^{-5}\right.$ to $\left.13.3 \mathrm{kPa}\right)$ with accuracies of \pm 5 percent in the 0.001 to 100 torr range and \pm 10 percent in the 0.0001 to 0.001 torr range. Pressures between a pair of seals or seal bulbs are monitored by two transducers, one rated for the high pressure range and one for vacuum conditions. A barometric pressure transducer (accuracy of $\pm 0.00737 \mathrm{psi}$ ) is used to measure the atmospheric pressure in the laboratory during testing.

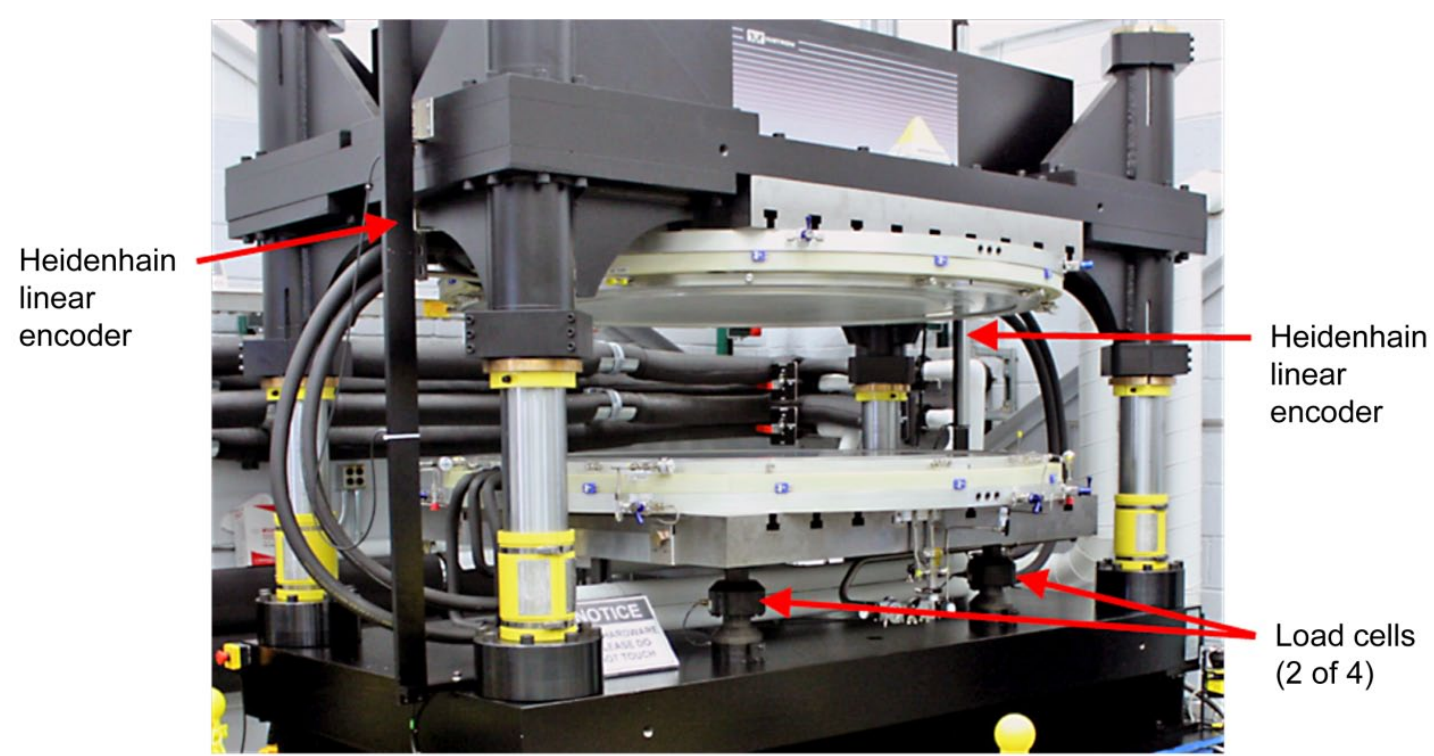

Figure 15.-Photograph of test apparatus showing locations of load cells and Heidenhain linear encoders. 
Seal leak rates can be measured by the test apparatus using either of two techniques. The first approach utilizes a mass point technique in which the mass of air within the test section is calculated based on samples of volume, pressure, and temperature measurements over time. A linear least-squares regression of the mass-time population is performed to yield the leak rate of the seal test specimen (Refs. 7, 8, and 9). The other leak testing approach utilizes a commercially available helium leak detector to quantify seal leak rates (Ref. 10). In this method, a constant supply of helium of known concentration is introduced in the region of atmospheric pressure upstream (inboard) of the seal test specimen. The helium leak detector is attached to the cavity downstream (outboard) of the seal. As helium leaks past or permeates through the seal, it flows into the mass spectrometer of the helium leak detector which measures the amount of helium and reports a leak rate.

In addition to instrumentation for seal performance, health monitoring instrumentation is included on the test apparatus in the form of a pressure gauge rated for 0 to $200 \mathrm{psig}$ ( 0 to $1379 \mathrm{kPa}$ ) that is used to measure the water pressure of the cooling line leading to the temperature control system. All of the data recorded during testing is collected using National Instruments data acquisition equipment and LabVIEW software (National Instruments).

\subsection{Analyses}

As the test apparatus was being designed and fabricated, analyses were performed for several of its main elements. The following sections summarize those analyses.

\subsection{Load Frame Analyses}

During fabrication and assembly of the load frame, it was discovered that the upper T-slotted plate experienced unexpected deformations when mounted to the movable crosshead. Measured deformations ranged from as much as $0.005 \mathrm{in}$. along the sides of the plate to about $0.001 \mathrm{in}$. across the front surface of the plate. It was determined that these deformations were due to gravitational loads deflecting the plate downward when the crosshead was attached to the actuator rod. These deformations also caused the crosshead to move in an unsteady, shuddering manner as it was actuated along the load frame columns. Because the flatness for the lower surface of the upper T-slotted plate was to be tightly controlled and these deflections were occurring before the test fixture was even installed, this condition was deemed unacceptable.

After identifying the problem, a series of structural analyses was performed to model the deflections and develop a plan to solve the problem. A simplified three-dimensional model was created in ANSYS including the crosshead plate with the upper T-slotted plate attached to it. The plate was supported in the center to simulate attachment to the actuator rod, and gravitational forces were applied. As shown in Figure 16, the deflections predicted by this analysis are very close to those that were measured on the actual hardware. Predicted deflections of 0.0042 to 0.0044 in. along the sides of the T-slotted plate compared favorably to the measured values of $0.005 \mathrm{in}$. while predictions along the front of the plate of $0.0007 \mathrm{in}$. were very close to the $0.001 \mathrm{in}$. value that was measured on the hardware.

Having established that the model accurately represented the actual hardware, additional analyses were performed on candidate solutions to minimize the amount of deformation in the plates. After evaluating multiple options, it was decided that a box structure should be added to the top surface of the crosshead plate. Box designs of several different heights were analyzed with each utilizing 2 in. thick steel plates to form the walls of the structure. Figure 17 shows the results of analyses performed on 16 and 18 in. tall box structures. Predicted deflections for both designs were on the order of $0.001 \mathrm{in}$. Based on the results of these analyses, it was decided that a $17 \mathrm{in}$. tall structure would be used for the final design. Figure 18 shows a photograph of the final structure installed on the top surface of the crosshead plate. 


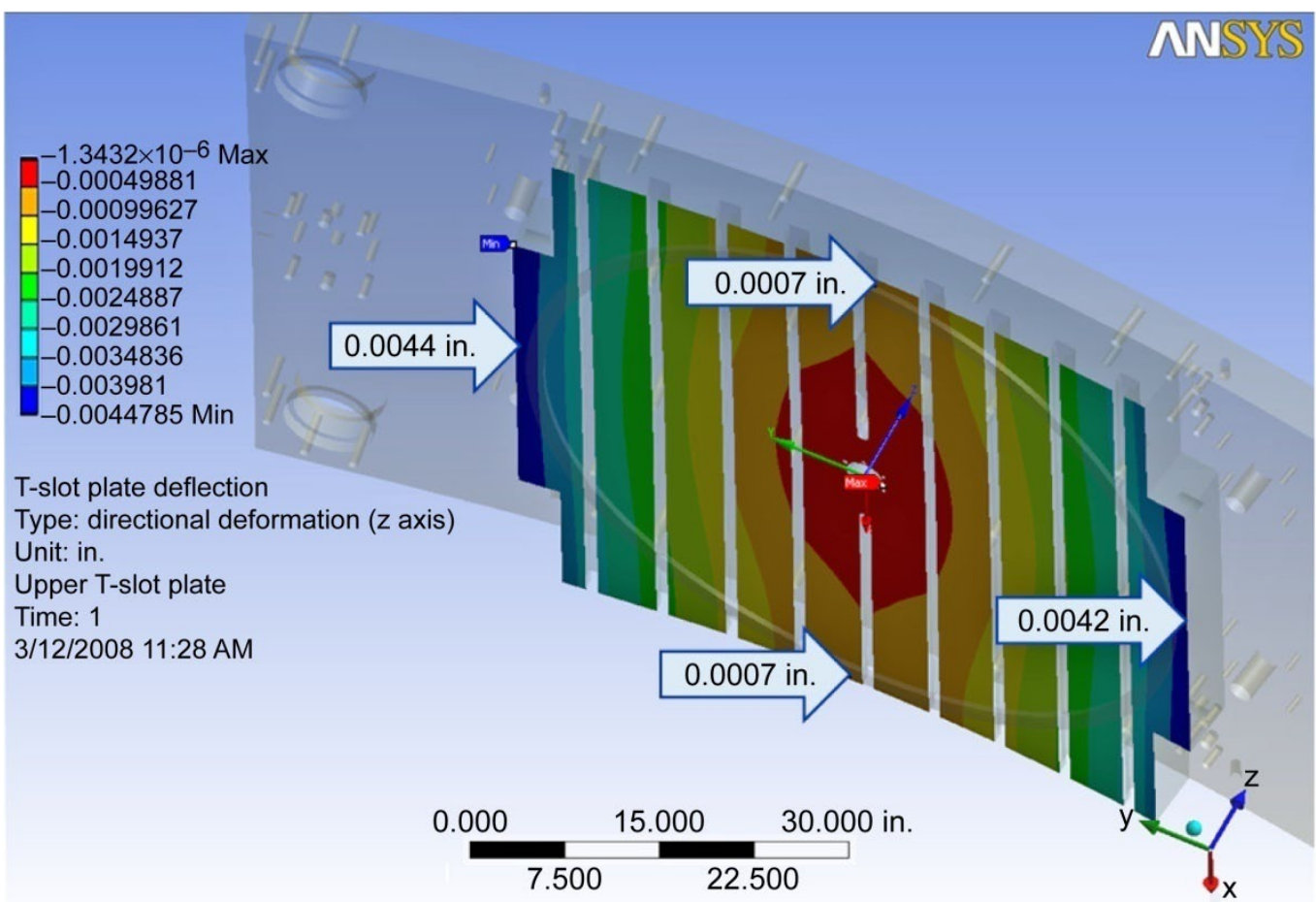

Figure 16.-Deflections predicted for baseline design of crosshead plate and upper T-slotted plate under gravitational load when supported in middle by actuator rod.

After fabrication and assembly of the load frame were completed and it was delivered to GRC and installed in the laboratory, the flatness of the upper T-slotted plate was measured to be $0.004 \mathrm{in}$. in its asinstalled state. Although this was higher than originally desired, it was deemed acceptable for two main reasons. The addition of the box structure to the top surface of the crosshead plate allowed the crosshead to move smoothly when it was actuated, eliminating the vibrations that occurred with the original design. The second reason was that although the flatness of the T-slotted plates was important, additional test fixture elements were being installed on top of the T-slotted plates, each with their own flatness. It was recognized that thin shims would need to be implemented in the test fixture assembly to achieve the desired flatness and parallelism at the test specimen sealing interface to accommodate minor out of flatness conditions for each of these multiple elements. 

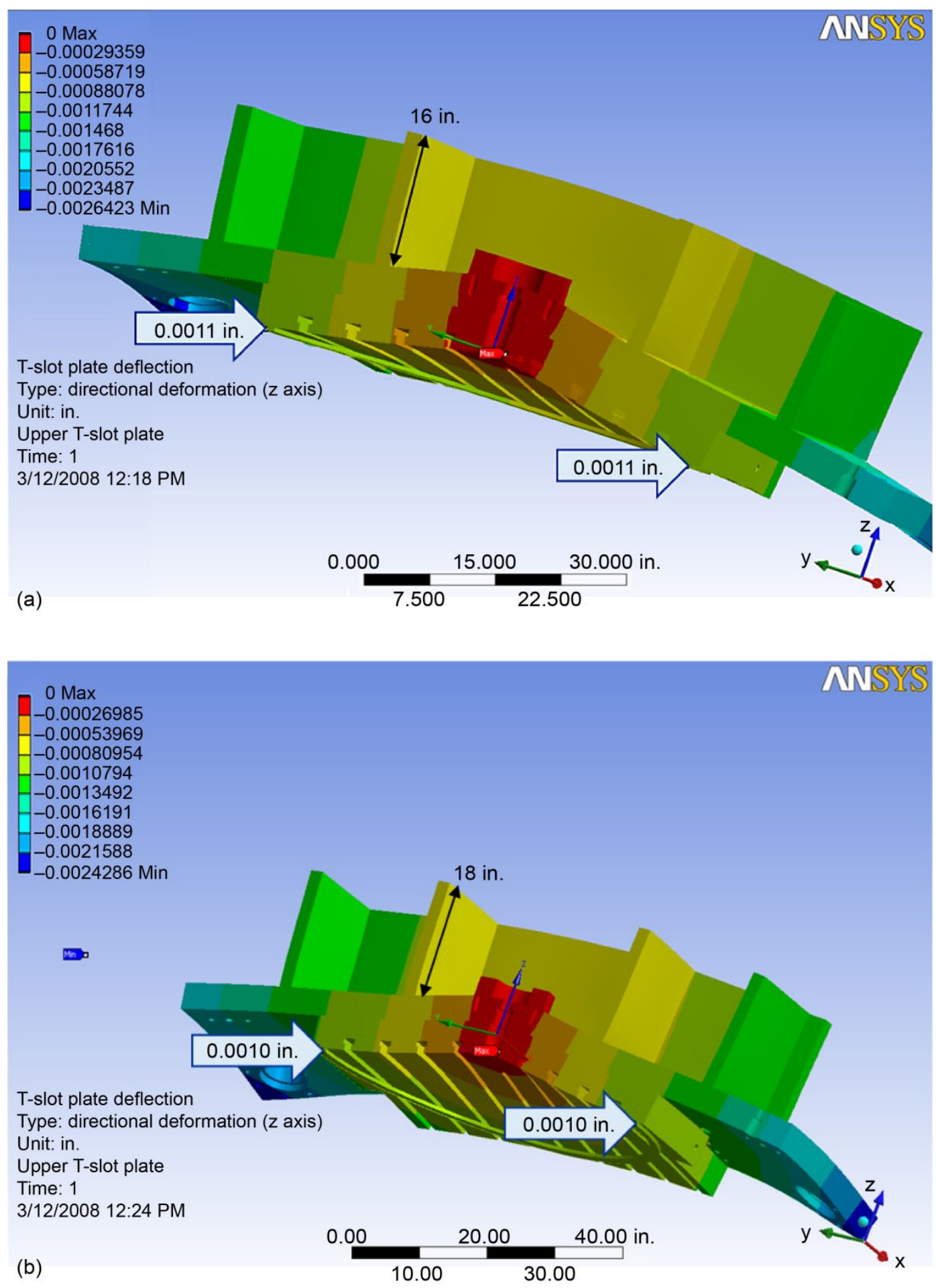

Figure 17.-Deflections predicted for new crosshead plate design with (a) 16 in. and (b) 18 in. tall box structures on top surface. Structures supported in middle by actuator rod with gravitational loads applied. 


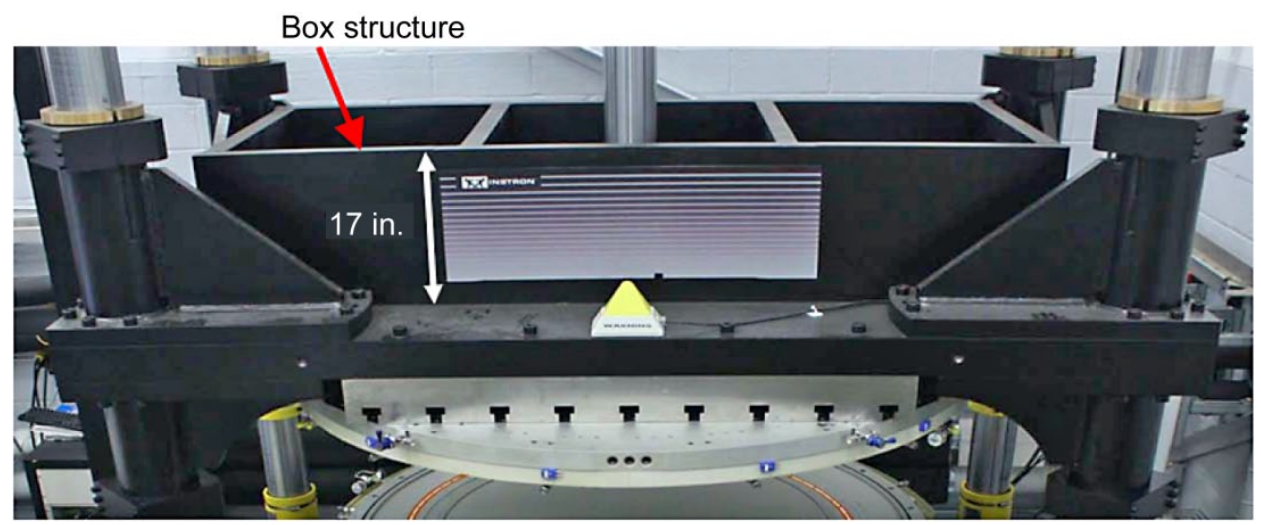

Figure 18.-Photograph of final 17 in. tall box structure installed on top surface of crosshead plate to minimize deflections.

\subsection{Base Support Structure Analyses}

As the test apparatus was being designed, estimated weights for the entire system were as high as $100 \mathrm{kip}$, and this load was to have been supported by I-beams below the lower base plate of the load frame. Calculations were performed to determine how much pressure would be applied to the floor of the laboratory, and the predicted loads under the I-beams were greater than the maximum allowable uniform live load for the floor of $1860 \mathrm{lb} / \mathrm{ft}^{2}$. If the original design using only I-beams for support would have been used, there were concerns that the laboratory floor could settle or crack due to the locally high Ibeam loads thereby affecting the stability and precision alignment of the test apparatus. Therefore, a support structure was designed and fabricated to distribute the weight of the heavy test apparatus more evenly on the floor.

A series of analyses was performed using ANSYS to guide the design of the support structure. The lower base plate, I-beams, and base support structure were all included in the model (Figure 19). Note that Figure 19 also identifies the locations for the four load cells on the lower base plate. Because the lower half of the test fixture is supported by the load cells, the deflections predicted by the analyses at these points were of interest. Analyses were performed in which the lower surface of the base support structure was only partially supported by the floor. This was accomplished by implementing nine "virtual support pads" in the model (Figure 20(a)). These features allowed the analyst to investigate cases in which the structure was supported by various combinations of pads representing hypothetical floor damage scenarios.

The first case that was evaluated simulated a scenario in which the floor under the base support structure had settled and was no longer supporting half of the structure. Figure 20(a) illustrates how the structure was partially supported by only six of the nine virtual support pads for this case. Even with a 100 kip load applied, the stresses in the structure were very low at 1 ksi or less. The deflections in the structure for this analysis case are shown in Figure 20(b). The deflection at the load cell location on the left side of the structure that was still supported was only $0.0005 \mathrm{in}$. On the right side the deflection at the load cell location was slightly higher at 0.0028 in., which was to be expected since this area was no longer supported by the floor. Although the deflections on the unsupported side of the structure were more than those for the supported side, the difference was quite small at only 0.0023 in. 

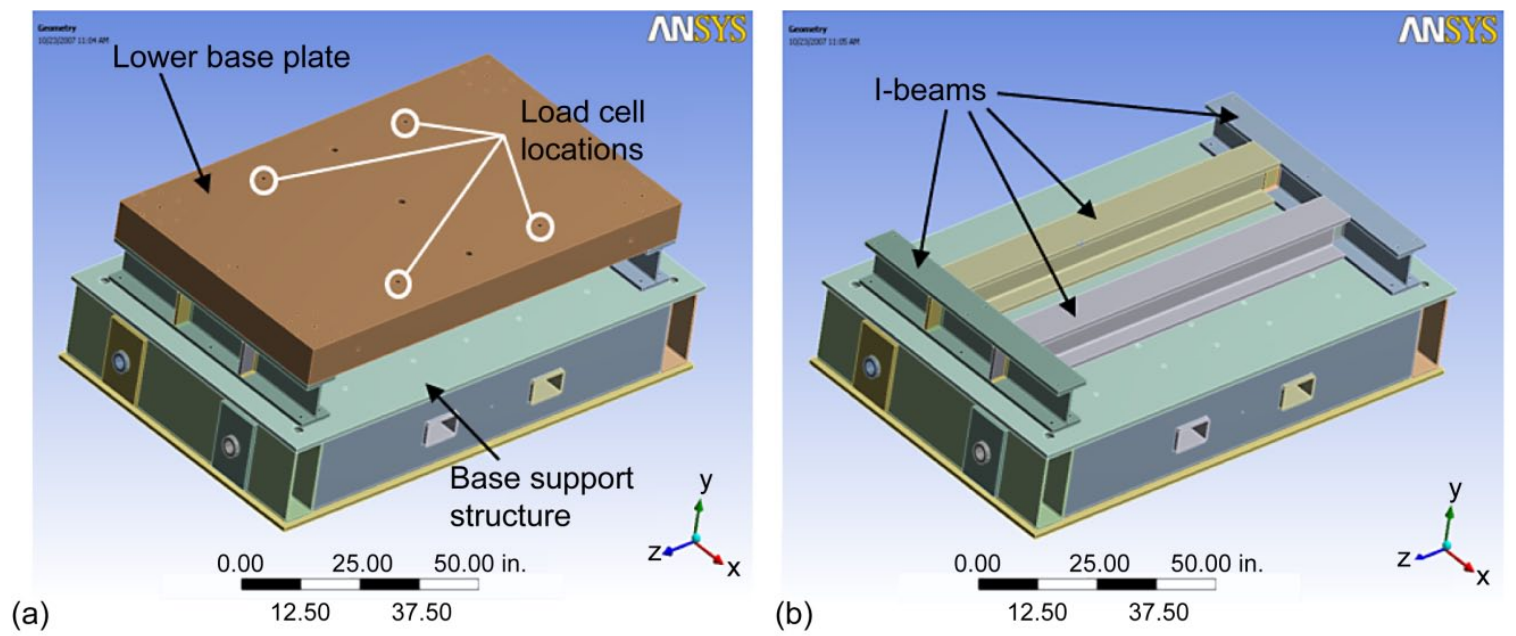

Figure 19.-ANSYS model used for structural analyses of base support structure: (a) entire model including lower base plate (with load cell locations noted), I-beams, and base support structure, and (b) view without lower base plate showing I-beams.
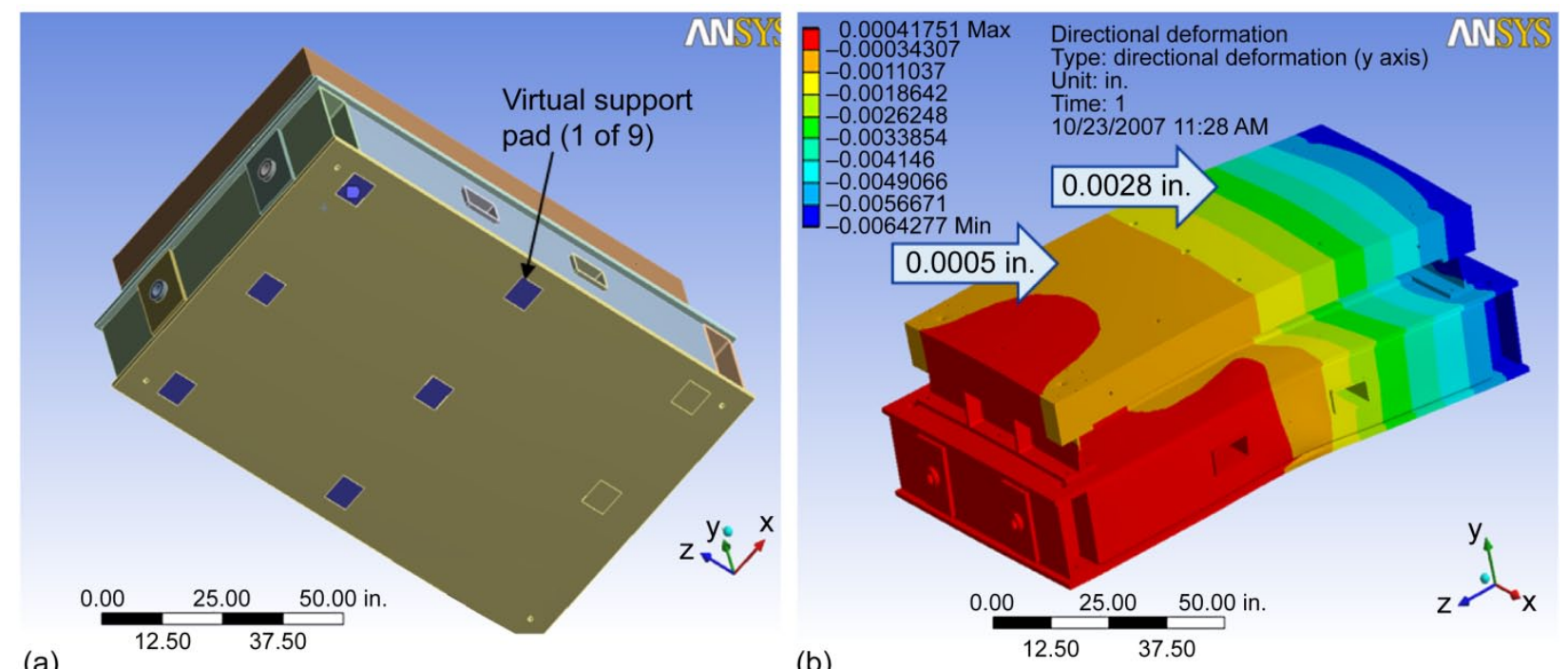

Figure 20.-Analysis results for base support structure partially supported under half of structure: (a) bottom view showing support at six of nine virtual support pads (blue squares) and (b) predicted deflections including those at load cell locations.

The second analysis case simulated an even more aggressive situation in which the base support structure was only supported by three of the nine support points along a diagonal (Figure 21(a)). As with the previous case, stresses were very low with most of the structure at less than $1 \mathrm{ksi}$. The predicted deflections shown in Figure 21(b) were fairly uniform along the diagonal where the structure was supported and increased near the two unsupported corners. Deflections predicted for the load cell locations were similar at 0.0009 and 0.0014 in. indicating that the top of the lower base plate remained relatively flat under this loading condition.

For both analysis cases, the predicted loads transmitted to the laboratory floor were also calculated yielding a maximum predicted load of $1465 \mathrm{lb} / \mathrm{ft}^{2}$ for the diagonal support case. This was below the maximum allowable uniform live load of $1860 \mathrm{lb} / \mathrm{ft}^{2}$ indicating that the new base support structure was more effective at distributing loads across the laboratory floor than the original I-beam design. 

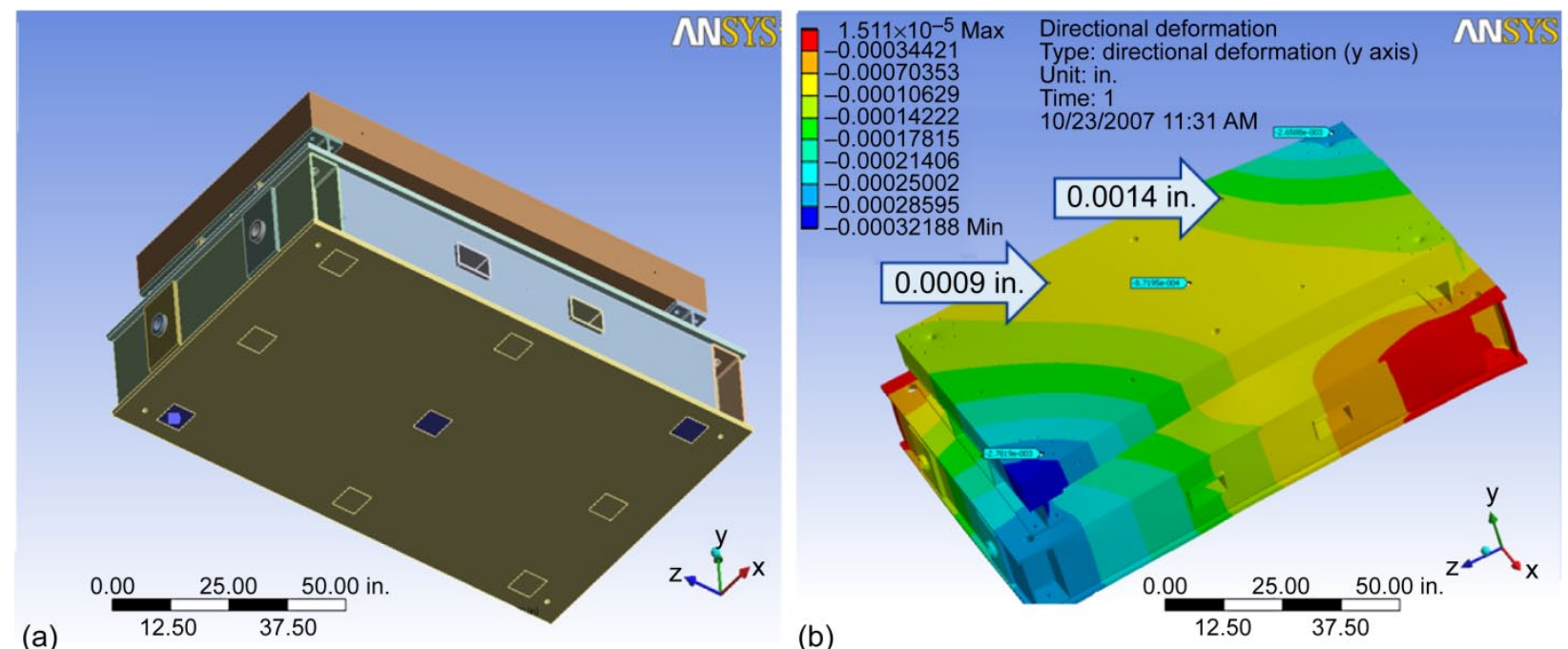

Figure 21.-Analysis results for base support structure partially supported along diagonal: (a) bottom view showing support at three of nine virtual support pads (blue squares) and (b) predicted deflections including those at load cell locations.

\subsection{Test Fixture Analyses}

Analyses were performed on the test fixture hardware to ensure that it could withstand the applied loads during testing. The model that was created in ANSYS focused on the lower half of the test fixture and included the seal plate assembly (seal cartridge and heat exchanger plates), insulator plate assembly, strongback, and T-slotted plate (Figure 4, Figure 5, and Figure 6). The loads used in the model simulated a case in which a seal test specimen was compressed and leak tested. The seal test specimen was modeled as a pair of $60 \mathrm{in}$. diameter seals with a stiffness of $100 \mathrm{lbf} / \mathrm{in}$. Compressive loads from O-rings inboard and outboard of the test seal were also applied (Figure 7), and the cavity between the inner O-ring and inner test seal was pressurized to simulate a leak test (Figure 9(a)). For conservatism, a pressure of 17 psig was used. For additional margin, a factor of 1.5 was applied to each load, resulting in a total force applied to the hardware of $103.6 \mathrm{kip}$. In addition to these testing loads, standard gravity was applied to the hardware.

The predicted peak stresses and factors of safety for each test fixture component in the model are summarized in Table 1. Material yield and ultimate strength properties used for the analyses came from References 5, 6, and 11. As seen in the table, stresses in the seal cartridge, heat exchanger plates, insulator plate assembly, and strongback were all very low at $1.3 \mathrm{ksi}$ or less, and factors of safety were all very high at 26.9 or greater. Peak stresses in the T-slotted plate were higher than those for the other components, but they were very localized where the plate was supported by the four load cells (Figure 22). Even at these higher predicted stresses, the factors of safety for the T-slotted plate were still 4.1 for yield strength and 5.3 for ultimate strength. At these low stresses, deflections in the test seal region were minimal at $0.003 \mathrm{in}$. or less. Based on the results of these analyses, the test fixture hardware was considered to be quite robust and capable of withstanding the anticipated loads during seal performance testing. 
TABLE 1.-PREDICTED PEAK STRESSES AND FACTORS OF SAFETY FOR MAIN TEST FIXTURE COMPONENTS.

\begin{tabular}{|c|c|c|c|c|c|}
\hline Component & Material & Criterion & $\begin{array}{c}\text { Material strength } \\
(\mathrm{ksi})\end{array}$ & $\begin{array}{c}\text { Peak stress } \\
(\mathrm{ksi})\end{array}$ & $\begin{array}{c}\text { Calculated } \\
\text { factor of safety }\end{array}$ \\
\hline \multirow[t]{2}{*}{ Seal cartridge } & \multirow{2}{*}{$\begin{array}{l}\text { 6061-T651 } \\
\text { Aluminum }\end{array}$} & Yield strength & 35 & \multirow[t]{2}{*}{1.1} & 31.8 \\
\hline & & Ultimate strength & 42 & & 38.2 \\
\hline \multirow[t]{2}{*}{ Heat exchanger plates } & \multirow{2}{*}{$\begin{array}{l}\text { 6061-T651 } \\
\text { Aluminum }\end{array}$} & Yield strength & 35 & \multirow[t]{2}{*}{1.3} & 26.9 \\
\hline & & Ultimate strength & 42 & & 32.3 \\
\hline \multirow[t]{2}{*}{ Insulator plate assembly } & \multirow{2}{*}{$\begin{array}{c}\text { G10 } \\
\text { Phenolic }\end{array}$} & Yield strength & 30 & \multirow[t]{2}{*}{0.2} & 150.0 \\
\hline & & Ultimate strength & 38 & & 190.0 \\
\hline \multirow[t]{2}{*}{ Strongback } & \multirow{2}{*}{$\begin{array}{l}\text { 6061-T651 } \\
\text { Aluminum }\end{array}$} & Yield strength & 35 & \multirow[t]{2}{*}{0.6} & 58.3 \\
\hline & & Ultimate strength & 42 & & 70.0 \\
\hline \multirow[t]{2}{*}{ T-slotted plate } & \multirow[t]{2}{*}{4140 Steel } & Yield strength & 99 & \multirow[t]{2}{*}{24.0} & 4.1 \\
\hline & & Ultimate strength & 128 & & 5.3 \\
\hline
\end{tabular}

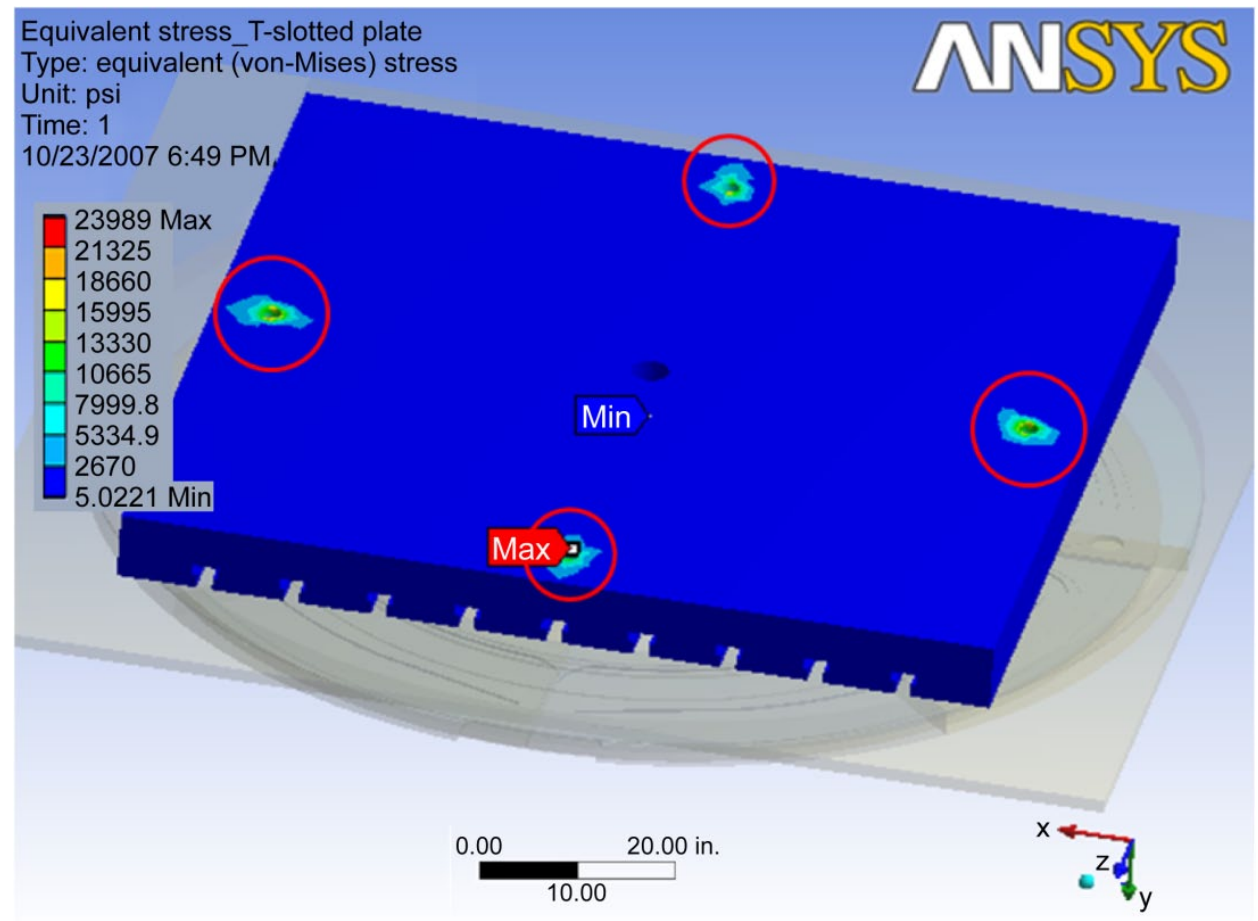

Figure 22.-View of bottom side of T-slotted plate showing predicted stresses including localized higher stresses at four load cell locations (in red circles).

\subsection{Summary}

NASA is developing advanced space-rated vacuum seals in support of future space exploration missions. These seals can have diameters on the order of 50 to $60 \mathrm{in}$. (127 to $152 \mathrm{~cm}$ ) and must exhibit extremely low leak rates to ensure that astronauts have sufficient breathable air for extended missions to the ISS and beyond. Seal compression and adhesion loads must also be below prescribed limits so as not to overload the mechanisms that compress them during docking or mating and to allow two mated systems to separate when required. 
GRC has developed a unique test apparatus to measure leak rates and compression and adhesion loads of candidate full-scale seals under simulated thermal, vacuum, and engagement conditions. This system consists of a specially-designed test fixture integrated into a custom load frame. Modular seal cartridges allow a variety of candidate seal designs and sizes to be tested in either a seal-on-seal or seal-on-flange mating configuration. Seal load and leak tests can be performed over a range of temperatures from -76 to $140{ }^{\circ} \mathrm{F}$ ( -60 to $60{ }^{\circ} \mathrm{C}$ ). Leak rates can be measured for fully or partially compressed seals using either a mass point technique or a commercially available helium leak detector at pressure differentials that the seals will experience on-orbit. Instrumentation located throughout the test apparatus measures seal performance including seal compression and adhesion loads, leak rates, pressures, and temperatures in addition to monitoring test apparatus health.

Development of this one-of-a-kind, full-scale seal test apparatus is a major accomplishment. It will be an asset to both NASA and international partners supporting advanced seal development and evaluations as well as qualification testing of full-scale seals for current and future space exploration vehicles. Once advanced seals are in use aboard an operational system, the test apparatus can also be used to assess onorbit anomalies if needed.

\section{References}

1. Parker O-Ring Handbook, Parker Hannifin Corporation, Cleveland, OH, 2007, pp. 4-2, 4-25.

2. Dunlap, P.H., Daniels, C.C., Steinetz, B.M., Erker, A.H., Robbie, M.G., Wasowski, J.L., Drlik, G.J., Tong, M.T., and Penney, N., "Full-Scale System for Quantifying Leakage of Docking System Seals for Space Applications," NASA/TM-2007-215024, AIAA-2007-5742, Oct. 2007.

3. Dunlap, P.H., Daniels, C.C., Wasowski, J.L., Garafolo, N.G., Penney, N., and Steinetz, B.M., "Pressure Decay Testing Methodology for Quantifying Leak Rates of Full-Scale Docking System Seals," NASA/TM-2010-216244, AIAA-2009-5319, Apr. 2010.

4. Wasowski, J.L., Penney, N., Garafolo, N.G., and Daniels, C.C., "Leak Rates of a Candidate Main Interface Seal at Selected Temperatures," AIAA-2009-5320, Aug. 2009.

5. G10 FR4 Technical Specifications, JJ Orly, Inc., 67 Walnut Avenue, Suite 307, Clark, NJ 07066, URL: http://www.jjorly.com/g10_fr4_technical_specifications_data.htm [cited Apr. 4, 2006].

6. "Metallic Materials and Elements for Aerospace Vehicle Structures," MIL-HDBK-5H, Dec. 1, 1998.

7. Garafolo, N.G. and Daniels, C.C., "Comprehensive Mass Point Leak Rate Technique. Part I: Methodology with Uncertainty and Experimental Error Analysis," The Fourth Japan-U.S.

Symposium on Emerging NDE Capabilities for a Safer World, American Society for Nondestructive Testing, Maui, HI, Jun. 7-11, 2010.

8. Daniels, C.C. and Garafolo, N.G., "Comprehensive Mass Point Leak Rate Technique. Part II: Application of Methodology and Variable Influences," The Fourth Japan-U.S. Symposium on Emerging NDE Capabilities for a Safer World, American Society for Nondestructive Testing, Maui, HI, Jun. 7-11, 2010.

9. Garafolo, N.G. and Daniels, C.C., "Compressible Advection through an Elastomer Seal: A Porous Media Approach to Seals for Space Applications," Proceedings of the ASME 2009 Fluids Engineering Division Summer Meeting, FEDSM2009-78067, ASME, Vail, CO, Aug. 2-5, 2009.

10. Varian Vacuum Products, Introduction to Helium Mass Spectrometer Leak Detection, 2nd ed., 1995.

11. Properties for AISI 4140 Steel, MatWeb, Material Property Data, 2020 Kraft Drive, Suite 3000, Blacksburg, VA 24060, http://www.matweb.com/search/ DataSheet.aspx?MatGUID=9f4b2e94285d46ecb679151a4aeb91d2 [cited Jun. 17, 2010]. 


\begin{tabular}{|c|c|c|}
\hline \multicolumn{2}{|c|}{ REPORT DOCUMENTATION PAGE } & $\begin{array}{l}\text { Form Approved } \\
\text { OMB No. 0704-0188 }\end{array}$ \\
\hline \multicolumn{3}{|c|}{$\begin{array}{l}\text { The public reporting burden for this collection of information is estimated to average } 1 \text { hour per response, including the time for reviewing instructions, searching existing data sources, gathering and maintaining the } \\
\text { data needed, and completing and reviewing the collection of information. Send comments regarding this burden estimate or any other aspect of this collection of information, including suggestions for reducing this } \\
\text { burden, to Department of Defense, Washington Headquarters Services, Directorate for Information Operations and Reports (0704-0188, } 1215 \text { Jefferson Davis Highway, Suite } 1204 \text {, Arlington, VA } 22222-4302 \text {. } \\
\text { Respondents should be aware that notwithstanding any other provision of law, no person shall be subject to any penalty for failing to comply with a collection of information if it does not display a currently valid OMB } \\
\text { control number. } \\
\text { PLEASE DO NOT RETURN YOUR FORM TO THE ABOVE ADDRESS. }\end{array}$} \\
\hline $\begin{array}{l}\text { 1. REPORT DATE (DD-MM-YYYY) } \\
01-12-2010\end{array}$ & $\begin{array}{l}\text { 2. REPORT TYPE } \\
\text { Technical Memorandum }\end{array}$ & 3. DATES COVERED (From - To) \\
\hline \multirow{3}{*}{\multicolumn{2}{|c|}{$\begin{array}{l}\text { 4. TITLE AND SUBTITLE } \\
\text { Full-Scale System for Quantifying Loads and Leak Rates of Seals for Space Applications }\end{array}$}} & 5a. CONTRACT NUMBER \\
\hline & & 5b. GRANT NUMBER \\
\hline & & 5c. PROGRAM ELEMENT NUMBER \\
\hline \multirow{3}{*}{\multicolumn{2}{|c|}{$\begin{array}{l}\text { 6. AUTHOR(S) } \\
\text { Dunlap, Patrick, H., Jr.; Steinetz, Bruce, M.; Daniels, Christopher, C.; Wasowski, Janice, L.; } \\
\text { Robbie, Malcolm, G.; Erker, Arthur, H.; Drlik, Gary, J.; Mayer, John, J. }\end{array}$}} & 5d. PROJECT NUMBER \\
\hline & & 5e. TASK NUMBER \\
\hline & & $\begin{array}{l}\text { 5f. WORK UNIT NUMBER } \\
\text { WBS 644423.06.31.04.01.03.22 }\end{array}$ \\
\hline \multicolumn{2}{|c|}{$\begin{array}{l}\text { 7. PERFORMING ORGANIZATION NAME(S) AND ADDRESS(ES) } \\
\text { National Aeronautics and Space Administration } \\
\text { John H. Glenn Research Center at Lewis Field } \\
\text { Cleveland, Ohio 44135-3191 }\end{array}$} & $\begin{array}{l}\text { 8. PERFORMING ORGANIZATION } \\
\text { REPORT NUMBER } \\
\text { E-17464 }\end{array}$ \\
\hline \multirow{2}{*}{\multicolumn{2}{|c|}{$\begin{array}{l}\text { 9. SPONSORING/MONITORING AGENCY NAME(S) AND ADDRESS(ES) } \\
\text { National Aeronautics and Space Administration } \\
\text { Washington, DC 20546-0001 }\end{array}$}} & $\begin{array}{l}\text { 10. SPONSORING/MONITOR'S } \\
\text { ACRONYM(S) } \\
\text { NASA }\end{array}$ \\
\hline & & $\begin{array}{l}\text { 11. SPONSORING/MONITORING } \\
\text { REPORT NUMBER } \\
\text { NASA/TM-2010-216885 }\end{array}$ \\
\hline \multicolumn{3}{|c|}{$\begin{array}{l}\text { 12. DISTRIBUTION/AVAILABILITY STATEMENT } \\
\text { Unclassified-Unlimited } \\
\text { Subject Category: } 37 \\
\text { Available electronically at http://gltrs.grc.nasa.gov } \\
\text { This publication is available from the NASA Center for AeroSpace Information, 443-757-5802 }\end{array}$} \\
\hline
\end{tabular}

\section{SUPPLEMENTARY NOTES}

\section{ABSTRACT}

NASA is developing advanced space-rated vacuum seals in support of future space exploration missions to low-Earth orbit and other destinations. These seals may be 50 to 60 in. $(127$ to $152 \mathrm{~cm})$ in diameter and must exhibit extremely low leak rates to ensure that astronauts have sufficient breathable air for extended missions to the International Space Station or the Moon. Seal compression loads must be below prescribed limits so as not to overload the mechanisms that compress them during docking or mating, and seal adhesion forces must be low to allow two mated systems to separate when required. NASA Glenn Research Center has developed a new test apparatus to measure leak rates and compression and adhesion loads of candidate full-scale seals under simulated thermal, vacuum, and engagement conditions. Tests can be performed in seal-on-seal or seal-on-flange configurations at temperatures from -76 to $140{ }^{\circ} \mathrm{F}\left(-60\right.$ to $\left.60^{\circ} \mathrm{C}\right)$ under operational pressure gradients. Nominal and off-nominal mating conditions (e.g., incomplete seal compression) can also be simulated. This paper describes the main design features of the test apparatus as well as techniques used to overcome some of the design challenges.

\section{SUBJECT TERMS}

Seals; Leakage; Compression tests; Adhesion tests; Load tests; Design

\begin{tabular}{|c|c|c|c|c|c|}
\hline \multicolumn{3}{|c|}{ 16. SECURITY CLASSIFICATION OF: } & \multirow{2}{*}{$\begin{array}{l}\text { 17. LIMITATION OF } \\
\text { ABSTRACT } \\
\text { UU }\end{array}$} & \multirow{2}{*}{$\begin{array}{l}\text { 18. NUMBER } \\
\text { OF } \\
\text { PAGES } \\
29\end{array}$} & \multirow{2}{*}{$\begin{array}{l}\text { 19a. NAME OF RESPONSIBLE PERSON } \\
\text { STI Help Desk (email:help@sti.nasa.gov) } \\
\text { 19b. TELEPHONE NUMBER (include area code) } \\
\text { 443-757-5802 }\end{array}$} \\
\hline $\begin{array}{l}\text { a. REPORT } \\
\text { U }\end{array}$ & $\begin{array}{l}\text { b. ABSTRACT } \\
\text { U }\end{array}$ & $\begin{array}{l}\text { c. THIS } \\
\text { PAGE } \\
\text { U }\end{array}$ & & & \\
\hline
\end{tabular}



